\title{
Iron-exchanged FAU zeolites: Preparation, characterization and catalytic properties for $\mathrm{N}_{2} \mathrm{O}$ decomposition
}

\author{
Landong $\mathrm{Li}^{\mathrm{a}}$, Qun Shen ${ }^{\mathrm{a}}$, Jinjun $\mathrm{Li}^{\mathrm{a}}$, Zhengping Hao ${ }^{\mathrm{a}, *}$, Zhi Ping Xu ${ }^{\mathrm{b}, * *}$, G.Q. Max Lu ${ }^{\mathrm{b}}$ \\ ${ }^{a}$ Research Center for Eco-Environmental Sciences, Chinese Academy of Sciences, Beijing 100085, PR China \\ ${ }^{\mathrm{b}}$ Australian Research Council (ARC) Centre of Excellence for Functional Nanomaterials, Australian Institute for Bioengineering and Nanotechnology \\ and School of Engineering, The University of Queensland, Brisbane, QLD 4072, Australia
}

\section{A R T I C L E I N F O}

\section{Article history:}

Received 7 March 2008

Received in revised form 9 April 2008

Accepted 9 April 2008

Available online 20 April 2008

\section{Keywords:}

Fe-zeolite catalysts

$\mathrm{N}_{2} \mathrm{O}$ decomposition

FAU

Wet ion exchange

\begin{abstract}
A B S T R A C T
New Fe-FAU zeolitic catalysts made from large channel zeolite matrix FAU by a simple wet ion exchange method show an excellent performance in $\mathrm{N}_{2} \mathrm{O}$ catalytic decomposition. The ion exchange process was discussed in detail and the optimal conditions for wet ion exchange were proposed. The formation of various iron sites in Fe-FAU samples (isolated Fe ions, oligonuclear clusters and $\mathrm{Fe}_{2} \mathrm{O}_{3}$ nanoparticles) during preparation process was extensively investigated by means of UV-vis spectra, FTIR spectra of NO adsorption, TEM images, $\mathrm{H}_{2}$-TPR and ${ }^{27} \mathrm{Al}$ MAS-NMR spectra. We have found that $\mathrm{Fe}(\mathrm{III})-\mathrm{FAU}$ catalysts more effectively decompose $\mathrm{N}_{2} \mathrm{O}$ with/out NO-assistance than other Fe-zeolite (such as Fe-MFI) catalysts prepared in the same way. Comprehensive understanding of the structure properties and the catalytic performance suggests that different iron sites in Fe-FAU make different contributions to $\mathrm{N}_{2} \mathrm{O}$ thermal decomposition and that isolated/oligonuclear iron species contribute more due to their high accessibility towards $\mathrm{N}_{2} \mathrm{O}$. In addition, the high durability of Fe-FAU catalysts is proposed to account for the particular interactions between iron species and zeolite framework.
\end{abstract}

(c) 2008 Elsevier B.V. All rights reserved.

\section{Introduction}

Incorporation of metal ions into a zeolite matrix brings about some special properties for heterogeneous catalysis. Iron zeolites, as an example, show high catalytic activity in many reactions, such as oxidation of benzene to phenol with nitrous oxide [1,2], selective catalytic reduction of nitrogen oxides [3-5], and direct decomposition of nitrous oxide [6-10]. As far as iron zeolite catalysts are concerned, the nature and distribution of active iron species are the key issue relevant to the catalytic activity. Some researchers have identified the iron species formed in the zeolites [11], however, their relationship with and contribution to the activity are not well demonstrated. It is well known that the formation of iron species in the zeolite matrix is directly related to the preparation procedure and conditions; thus in this research, we aim to illustrate the effects of preparation parameters on the formation of iron species in zeolite and to understand how their distribution is related to their catalytic performance.

In general, iron-zeolite catalysts were prepared by wet ion exchange with ferrous salt [12] or ferric salt [13], solid-state ion

\footnotetext{
* Corresponding author. Tel.: +86 10 62923564; fax: +86 1062923564 .

** Corresponding author. Tel.: +61 7 33463809; fax: +61 733363973.

E-mail addresses: zpinghao@rcees.ac.cn (Z. Hao), gordonxu@uq.edu.au (Z.P.Xu).
}

exchange [14], chemical vapor decomposition (CVD) of $\mathrm{FeCl}_{3}$ [15], and isomorphous substitution followed by extraction at elevated temperatures [16]. Wet ion exchange is simpler and more feasible for industrial applications as it involves fewer steps and the preparation parameters are more easily controlled. To evenly distribute the iron species into the channel by this method, one should assure that the channel dimension of the host zeolite is large enough for the hydrated/hydrolyzed iron ions to freely diffuse, so that FAU with a large channel dimension ([ $\left.\begin{array}{lll}1 & 1 & 1\end{array}\right]$ $0.74 \times 0.74 \mathrm{~nm}$ ) was chosen as the host to simplify the preparation parameters affecting the iron species formation in this research. In fact, $\mathrm{Fe}(\mathrm{III})$ ion exchanged FAU zeolites were examined as catalysts for several other reactions $[17,18]$, while they did not show a good apparent catalytic activity for the $\mathrm{N}_{2} \mathrm{O}$ decomposition [19]. However, our recent results indicated that $\mathrm{Fe}(\mathrm{III})$-USY zeolite catalyst is very active in the direct $\mathrm{N}_{2} \mathrm{O}$ decomposition, even better than any other Fe-zeolite catalysts [20]; we attributed this activity to the high and well dispersed Fe(III) loading in the channels. For comparison, a few other kinds of $\mathrm{Fe}(\mathrm{II})$ and $\mathrm{Fe}(\mathrm{III})$ zeolites were made in the same way. In brief, we have identified iron species formed in the zeolites by comprehensively analyzing the information revealed by the UV-vis spectra, the FTIR spectra of adsorbed probe molecule NO, the ${ }^{27} \mathrm{Al}$ NMR spectra and the TEM images. Our analysis relating the iron species and catalytic performance does not show that either the isolated $\mathrm{Fe}(\mathrm{III})$ species 
or the oligonuclear $\mathrm{Fe}(\mathrm{III})_{x} \mathrm{O}_{y}$ cluster is more active for $\mathrm{N}_{2} \mathrm{O}$ decomposition, but suggests that not all isolated/oligonuclear $\mathrm{Fe}$ (III) sites make the same (or similar) contributions to the activity, since the site accessibility is an important factor. Fe(III)-USY catalyst thus shows a potential in the end-of-pipe treatment of $\mathrm{N}_{2} \mathrm{O}$ emission from a nitric acid plant both in the catalytic activity and the durability.

\section{Experimental}

\subsection{Catalyst preparation}

Commercial H-ZSM-5 (Si/Al = 11.8), Na-Y (Si/Al = 3.8), H-Y (Si/ $\mathrm{Al}=5.4)$ and ultra-stable $\mathrm{Y}(\mathrm{USY}, \mathrm{Si} / \mathrm{Al}=11.6)$ were purchased from Sinopec Co. and directly used as parent zeolites for ion exchange (Table 1). In general, various iron-containing zeolite catalysts were prepared by wet ion exchange using ferric salt or ferrous salt at room temperature for $48 \mathrm{~h}$ and subsequent calcination at $873 \mathrm{~K}$ for $4 \mathrm{~h}$. For example, $2.0 \mathrm{~g}$ of the parent zeolite was exchanged with $200 \mathrm{ml} 0.05 \mathrm{M} \mathrm{FeCl}_{3}(\mathrm{pH} \sim 1.8)$ for $48 \mathrm{~h}$ under vigorous stirring to load $\mathrm{Fe}(\mathrm{III})$. To load nominal $\mathrm{Fe}(\mathrm{II})$, we exchanged $2.0 \mathrm{~g}$ of the parent zeolite with $200 \mathrm{ml} 0.05 \mathrm{M} \mathrm{FeSO}_{4}(\mathrm{pH} \sim 3.0$ ) for $48 \mathrm{~h}$ under vigorous stirring in the flowing $\mathrm{N}_{2}$ stream. The as-exchanged samples were then filtered, thoroughly washed, dried at $353 \mathrm{~K}$ and calcined at $873 \mathrm{~K}$ for $4 \mathrm{~h}$ in the air. In particular, as-obtained Fe(II)USY and Fe(III)-USY were further treated with $0.01 \mathrm{M} \mathrm{HCl}$ at room temperature for $6 \mathrm{~h}$, followed by filtration, through washing, drying at $353 \mathrm{~K}$ and calcination at $873 \mathrm{~K}$ for $4 \mathrm{~h}$ in the air (named as Fe(II)-USY-A and Fe(III)-USY-A, respectively). These iron zeolite catalysts, as denoted in Table 1, were then crushed and sized in 2040 mesh, and kept in a desiccator for subsequent characterization and $\mathrm{N}_{2} \mathrm{O}$ decomposition tests.

\subsection{Catalyst characterization}

The $\mathrm{Si}, \mathrm{Al}$ and $\mathrm{Fe}$ contents in these iron-containing zeolites were analyzed by ICP-OES using an Optima 2000 spectrometer, and their specific surface area was determined through low temperature $\mathrm{N}_{2}$ adsorption/desorption isotherms collected on a Quantachrome NOVA-1200 gas absorption analyzer. The X-ray diffraction (XRD) patterns of parent and iron-exchanging zeolites were recorded on a Rigaku powder diffractometer (D/MAX-RB) using $\mathrm{Cu}-\mathrm{K}_{\alpha}$ radiation $(\lambda=0.15418 \mathrm{~nm})$ at a scanning rate of $4 \%$ min in $2 \theta=5-35^{\circ}$.

UV-vis measurements were carried out on a Hitachi UV-3000 spectrometer, and diffuse reflectance (DR) spectra were recorded in the air against $\mathrm{BaSO}_{4}$ in the region of $190-800 \mathrm{~nm}$ at a resolution of $1 \mathrm{~nm}$. The ${ }^{27} \mathrm{Al}$ MAS-NMR spectra were recorded on a Bruker DRX400 spectrometer $(9.4 \mathrm{~T})$. The samples were spun in the rotors. The r.f. pulse with the length of $0.3 \mu$ s was applied and the MAS frequency was fixed at $20 \mathrm{kHz}$. The spectrum was acquired after

Table 1

Preparation and physicochemical properties of iron-zeolites

\begin{tabular}{|c|c|c|c|c|c|}
\hline Sample & Fe source & $\mathrm{Si} / \mathrm{Al}^{\mathrm{a}}$ & $\mathrm{Fe} / \mathrm{Al}^{\mathrm{b}}$ & $\mathrm{Fe}(\mathrm{wt} \%)$ & $S_{\mathrm{BET}}\left(\mathrm{m}^{2} / \mathrm{g}\right)$ \\
\hline $\mathrm{Fe}(\mathrm{II})-\mathrm{ZSM}-5$ & $\mathrm{FeSO}_{4}$ & $12.4(11.8)$ & 0.24 & 1.81 & 418.7 \\
\hline Fe(III)-ZSM-5 & $\mathrm{FeCl}_{3}$ & $12.1(11.8)$ & 0.04 & 0.30 & 422.8 \\
\hline $\mathrm{Fe}(\mathrm{II})-\mathrm{USY}$ & $\mathrm{FeSO}_{4}$ & $11.9(11.6)$ & 0.36 & 2.79 & 534.3 \\
\hline $\mathrm{Fe}(\mathrm{II})-\mathrm{USY}-\mathrm{A}$ & Acid-treated & 15.1 (11.9) & 0.32 & 1.96 & 541.4 \\
\hline Fe(III)-USY & $\mathrm{FeCl}_{3}$ & $12.3(11.6)$ & 0.44 & 3.38 & 527.8 \\
\hline Fe(III)-USY-A & Acid-treated & $16.8(12.3)$ & 0.37 & 2.06 & 535.8 \\
\hline $\mathrm{Fe}(\mathrm{III})-\mathrm{NaY}$ & $\mathrm{FeCl}_{3}$ & $5.3(3.8)$ & 0.35 & 6.16 & 456.3 \\
\hline $\mathrm{Fe}(\mathrm{III})-\mathrm{HY}$ & $\mathrm{FeCl}_{3}$ & $6.7(5.4)$ & 0.39 & 5.43 & 562.6 \\
\hline
\end{tabular}

${ }^{\mathrm{a}}$ The number in parentheses is the $\mathrm{Si} / \mathrm{Al}$ atomic ratio before iron exchange or acid treatment.

b The Fe/Al atomic ratio should be 0.33 with ferric ions completely exchanging, while it should be 0.50 with ferrous ions fully exchanging.
2000 accumulations with the acquisition time of $0.1 \mathrm{~s}$. A time interval of $1 \mathrm{~s}$ was selected between two successive accumulations to avoid saturation effects. Saturated $\mathrm{Al}\left(\mathrm{NO}_{3}\right)_{3}$ solution was used as the ${ }^{27} \mathrm{Al}$ chemical shift reference.

Transmission electron microscopy (TEM) images of the Fecontaining zeolite catalysts were acquired on a JEOL 3010 transmission electron microscope at an acceleration voltage of $300 \mathrm{kV}$. A few drops of alcohol suspension containing the catalyst sample were placed on a carbon-coated copper grid, followed by evaporation at ambient temperature.

The $\mathrm{H}_{2}$ temperature-programmed reduction (TPR) of asprepared catalysts was carried out in a microreactor using $5 \mathrm{vol} \% \mathrm{H}_{2} / \mathrm{He}$ at a heating rate of $5 \mathrm{~K} / \mathrm{min}$ from 323 to $1173 \mathrm{~K}$. Prior to reduction, the catalyst ( $50 \mathrm{mg}$ ) was treated in He at $873 \mathrm{~K}$ for $2 \mathrm{~h}$. During the heating from 323 to $1173 \mathrm{~K}$, the $\mathrm{H}_{2}$ consumption was measured online with a gas chromatograph equipped with a TCD.

FTIR spectra of NO adsorption on these Fe-zeolite catalysts were collected on the spectrometer (Bruker Tensor 27) with 128 scans at a resolution of $4 \mathrm{~cm}^{-1}$. A self-supporting pellet (about $50 \mathrm{mg}$ ) made of the catalyst sample was placed in the IR flow cell and the reference spectrum (i.e. background spectrum) was taken at room temperature $(298 \mathrm{~K})$. After the He stream was switched to a gas mixture containing $1 \% \mathrm{NO}$ in He at a total flow rate of $30 \mathrm{ml} / \mathrm{min}$, a series of time-dependent FTIR spectra of NO adsorption on the zeolite catalyst were sequentially recorded.

\subsection{Activity measurements}

$\mathrm{N}_{2} \mathrm{O}$ decomposition experiments were performed in a fixed-bed flow microreactor at ambient pressure. In each run, $0.1 \mathrm{~g}$ catalyst (sieve fraction in 20-40 mesh) was placed in a quartz reactor ( $4 \mathrm{~mm}$ i.d.) and pretreated in He at $873 \mathrm{~K}$ for $1 \mathrm{~h}$. After the reactor was cooled to $573 \mathrm{~K}$, the reactant gas mixture (1500 ppm $\mathrm{N}_{2} \mathrm{O}$, with/out $5 \% \mathrm{O}_{2}$ or $200 \mathrm{ppm}$ NO; He balance) was fed to the reactor. The total flow rate of the mixed gases was set at $60 \mathrm{ml} / \mathrm{min}$, corresponding to GHSV $=30,000 \mathrm{~h}^{-1}$. The outlet gas composition was analyzed online using a gas chromatograph (Agilent 6820 series) equipped with a TCD detector and two serial columns (a Porapak Q column served for the separation of $\mathrm{N}_{2} \mathrm{O}$ and $\mathrm{N}_{2} / \mathrm{O}_{2}$, and a molecular sieve $5 \mathrm{~A}$ column for the separation of $\mathrm{N}_{2}$ and $\mathrm{O}_{2}$ ). The steady-state $\mathrm{N}_{2} \mathrm{O}$ conversion at a temperature ascending from 573 to $873 \mathrm{~K}$ at $25 \mathrm{~K}$ intervals was calculated based on the GC peak area. For the durability test of $\mathrm{Fe}(\mathrm{III})$-USY sample, we chose a constant temperature ( 723 or $748 \mathrm{~K}$ ) and monitored the conversion of $\mathrm{N}_{2} \mathrm{O}$ for $100 \mathrm{~h}$ in a simulated gas mixture (1500 ppm $\mathrm{N}_{2} \mathrm{O}, 5 \% \mathrm{O}_{2}, 1 \% \mathrm{H}_{2} \mathrm{O}$ and 200 ppm NO; He balance).

\section{Results and discussion}

\subsection{Solution behavior of ferric and ferrous ions}

For hydrated ferric ions, the following stepwise hydrolyses occur in aqueous solution, accompanied by the condensation reaction $[21,22]$ :

$$
\begin{aligned}
& \mathrm{Fe}\left(\mathrm{H}_{2} \mathrm{O}\right)_{6}{ }^{3+}+\mathrm{H}_{2} \mathrm{O} \Leftrightarrow \mathrm{Fe}\left(\mathrm{H}_{2} \mathrm{O}\right)_{5}(\mathrm{OH})^{2+}+\mathrm{H}_{3} \mathrm{O}^{+} \quad(\log \mathrm{K}=-2.13) \\
& \mathrm{Fe}\left(\mathrm{H}_{2} \mathrm{O}\right)_{5}(\mathrm{OH})^{2+}+\mathrm{H}_{2} \mathrm{O} \\
& \quad \Leftrightarrow \mathrm{Fe}\left(\mathrm{H}_{2} \mathrm{O}\right)_{4}(\mathrm{OH})_{2}{ }^{+}+\mathrm{H}_{3} \mathrm{O}^{+} \quad(\log \mathrm{K}=-3.30) \\
& 2 \mathrm{Fe}\left(\mathrm{H}_{2} \mathrm{O}\right)_{6}{ }^{3+}+\mathrm{H}_{2} \mathrm{O} \\
& \quad \Leftrightarrow \mathrm{Fe}\left(\mathrm{H}_{2} \mathrm{O}\right)_{5}(\mathrm{O}) \mathrm{Fe}\left(\mathrm{H}_{2} \mathrm{O}\right)_{5}{ }^{4+}+2 \mathrm{H}_{3} \mathrm{O}^{+} \quad(\log \mathrm{K}=-2.91)
\end{aligned}
$$

At $\mathrm{pH} \sim 1.8$, the second hydrolysis reaction can be ignored. The main ferric ion species are $\mathrm{Fe}\left(\mathrm{H}_{2} \mathrm{O}\right)_{6}{ }^{3+}(60 \%), \mathrm{Fe}\left(\mathrm{H}_{2} \mathrm{O}\right)_{5}(\mathrm{OH})^{2+}(25 \%)$ 
and $\mathrm{Fe}\left(\mathrm{H}_{2} \mathrm{O}\right)_{5}(\mathrm{O}) \mathrm{Fe}\left(\mathrm{H}_{2} \mathrm{O}\right)_{5}{ }^{4+}(15 \% \mathrm{Fe})$ if the total $\left[\mathrm{Fe}^{3+}\right]=0.05 \mathrm{M}$. The $\mathrm{Fe}^{3+}-\mathrm{O}$ distance is reported to be ca. $0.20 \mathrm{~nm}$ [23] and van der Waals' radius of water (or oxygen) is known to be $0.14 \mathrm{~nm}$. Thus, the diameter of $\mathrm{Fe}\left(\mathrm{H}_{2} \mathrm{O}\right)_{6}{ }^{3+}$ ion is estimated as $\mathrm{ca} .0 .68 \mathrm{~nm}$ and $\mathrm{Fe}\left(\mathrm{H}_{2} \mathrm{O}\right)_{5}(\mathrm{OH})^{2+}$ has almost the same diameter. The volume mean diameter of $\mathrm{Fe}\left(\mathrm{H}_{2} \mathrm{O}\right)_{5}(\mathrm{O}) \mathrm{Fe}\left(\mathrm{H}_{2} \mathrm{O}\right)_{5}{ }^{4+}$ is calculated to be $0.90 \mathrm{~nm}$. For ferrous ions, any hydrolysis reaction can be ignored under acid conditions ( $\mathrm{pH} 3.0)$ :

$\mathrm{Fe}\left(\mathrm{H}_{2} \mathrm{O}\right)_{6}{ }^{2+}+\mathrm{H}_{2} \mathrm{O} \Leftrightarrow \mathrm{Fe}\left(\mathrm{H}_{2} \mathrm{O}\right)_{5}(\mathrm{OH})^{+}+\mathrm{H}_{3} \mathrm{O}^{+} \quad(\log K=-5.56)$

$\mathrm{Fe}\left(\mathrm{H}_{2} \mathrm{O}\right)_{5}(\mathrm{OH})^{+}+\mathrm{H}_{2} \mathrm{O} \Leftrightarrow \mathrm{Fe}\left(\mathrm{H}_{2} \mathrm{O}\right)_{4}(\mathrm{OH})_{2}+\mathrm{H}_{3} \mathrm{O}^{+} \quad(\log \mathrm{K}=-9.77)$

Thus the only aqueous iron species is the hydrated ferrous ion $\left(\mathrm{Fe}\left(\mathrm{H}_{2} \mathrm{O}\right)_{6}{ }^{2+}\right)$. As the $\mathrm{Fe}^{2+}-\mathrm{O}$ distance is ca. $0.21 \mathrm{~nm}$ [24], the diameter of the $\mathrm{Fe}\left(\mathrm{H}_{2} \mathrm{O}\right)_{6}{ }^{2+}$ ion is thus $0.70 \mathrm{~nm}$.

\subsection{Factors affecting the Fe loading in zeolites}

As listed in Table 1, the $\mathrm{Si} / \mathrm{Al}$ atomic ratio in each Fe-zeolite is increased to some degree in comparison with its parent zeolite, due to dealumination (by 3-30\%) from the framework at the acidic exchanging medium. The increase of the Si/Al ratio in the acidtreated USY samples (highlighted in bold in Table 1) suggests a further dealumination (by 20-25\%) from the zeolite framework.

Theoretically, complete ion exchange in zeolites can give the $\mathrm{Fe} /$ Al ratio up to 0.50 in $\mathrm{Fe}(\mathrm{II})$-zeolites and 0.33 in $\mathrm{Fe}(\mathrm{III})$-zeolites. Table 1 shows that the Fe/Al ratio in Fe(II)-zeolites is 0.24-0.36, $50-70 \%$ of its maximum exchange amount. In contrast, this ratio in $\mathrm{Fe}(\mathrm{III})-$ zeolites is $0.35-0.44$ (except for $\mathrm{Fe}(\mathrm{III})-\mathrm{ZSM}-5$ ), a bit more than the expected value (0.33). Note that the iron loading in USY is much higher than that in ZSM-5 for both $\mathrm{Fe}^{2+}$ and $\mathrm{Fe}^{3+}$ exchange (Table 1 ), probably due to the larger channel size in USY, as will be addressed shortly. In addition, different parent zeolites with the same faujasite (FAU) structure (Na-Y, H-Y and USY) were exchanged with $\mathrm{Fe}^{3+}$ where a similar $\mathrm{Fe} / \mathrm{Al}$ ratio $(0.35-0.44)$ was achieved. Therefore, the Fe loading is very much relevant to the Fe source and to the zeolite types.

In our opinion, the channel size of the zeolites and the iron ion species available for exchange play key roles in determining the $\mathrm{Fe}$ loading in zeolite. In the case of $\mathrm{Fe}^{2+}$ exchange, hydrated ferrous ion $\left(\mathrm{Fe}\left(\mathrm{H}_{2} \mathrm{O}\right)_{6}{ }^{2+}\right)$ is the only ion species in aqueous solution at room temperature and $\mathrm{pH} \sim 3$, having the size of $0.70 \mathrm{~nm}$. Therefore, $\mathrm{Fe}\left(\mathrm{H}_{2} \mathrm{O}\right)_{6}{ }^{2+}$ can readily diffuse into USY faujasite with the channel size of [ $\left.\begin{array}{lll}1 & 1 & 1\end{array}\right] 0.74 \times 0.74 \mathrm{~nm}$, and thus achieve a high ion exchange extent ( $\mathrm{Fe} / \mathrm{Al}=0.36$ for $\mathrm{Fe}(\mathrm{II})$-USY). This is still much smaller than the full exchange $(\mathrm{Fe} / \mathrm{Al}=0.50)$, as also reported elsewhere $[9,25]$, very likely due to oxidation of $\mathrm{Fe}(\mathrm{II})$ to $\mathrm{Fe}(\mathrm{III})$ during the exchange. However, ZSM-5 has the channel size of $\left[\begin{array}{lll}1 & 0 & 0\end{array}\right] 0.51 \times 0.55 \mathrm{~nm} \leftrightarrow\left[\begin{array}{lll}0 & 1 & 0\end{array}\right] 0.53 \times 0.56 \mathrm{~nm}$, so it is difficult for $\mathrm{Fe}\left(\mathrm{H}_{2} \mathrm{O}\right)_{6}{ }^{2+}$ to diffuse into all the ZSM-5 channels, leading to a lower exchange degree ( $\mathrm{Fe} / \mathrm{Al}=0.24$ for $\mathrm{Fe}(\mathrm{II})-\mathrm{ZSM}-5)$.

In comparison, the main ferric ion species are $\mathrm{Fe}\left(\mathrm{H}_{2} \mathrm{O}\right)_{6}{ }^{3+}(60 \%)$, $\mathrm{Fe}\left(\mathrm{H}_{2} \mathrm{O}\right)_{5}(\mathrm{OH})^{2+}(25 \%)$ and $\mathrm{Fe}\left(\mathrm{H}_{2} \mathrm{O}\right)_{5}(\mathrm{O}) \mathrm{Fe}\left(\mathrm{H}_{2} \mathrm{O}\right)_{5}{ }^{4+}(15 \% \mathrm{Fe})$ in aqueous solution at $\mathrm{pH} \sim 1.8$ and room temperature (total $[\mathrm{Fe}]=0.05 \mathrm{M}$ ), with sizes being $0.68,0.68$ and $0.90 \mathrm{~nm}$, respectively. Obviously, $\mathrm{Fe}\left(\mathrm{H}_{2} \mathrm{O}\right)_{5}(\mathrm{O}) \mathrm{Fe}\left(\mathrm{H}_{2} \mathrm{O}\right)_{5}{ }^{4+}$ is much larger than the channel size of USY faujasite ([ $\left.\left.\begin{array}{lll}1 & 1 & 1\end{array}\right] 0.74 \times 0.74 \mathrm{~nm}\right)$. Therefore it could be very difficult for this hydrolyzed ion to diffuse into the interior zeolite channel and join the proton exchange. $\mathrm{Fe}\left(\mathrm{H}_{2} \mathrm{O}\right)_{6}{ }^{3+}$ and $\mathrm{Fe}\left(\mathrm{H}_{2} \mathrm{O}\right)_{5}(\mathrm{OH})^{2+}$ are smaller than the channel size of USY faujasite ([ $\left[\begin{array}{lll}1 & 1 & 1\end{array}\right] 0.74 \times 0.74 \mathrm{~nm}$ ) and can readily diffuse into the channels to exchange. We believe that $\mathrm{Fe}\left(\mathrm{H}_{2} \mathrm{O}\right)_{5}(\mathrm{OH})^{2+}$ ion is more preferred, because the exchange of high positively charged ions $\mathrm{Fe}\left(\mathrm{H}_{2} \mathrm{O}\right)_{6}{ }^{3+}$ in silicon-rich zeolites is more difficult. Therefore, maximizing the $\mathrm{Fe}\left(\mathrm{H}_{2} \mathrm{O}\right)_{5}(\mathrm{OH})^{2+}$ concentration and minimizing the

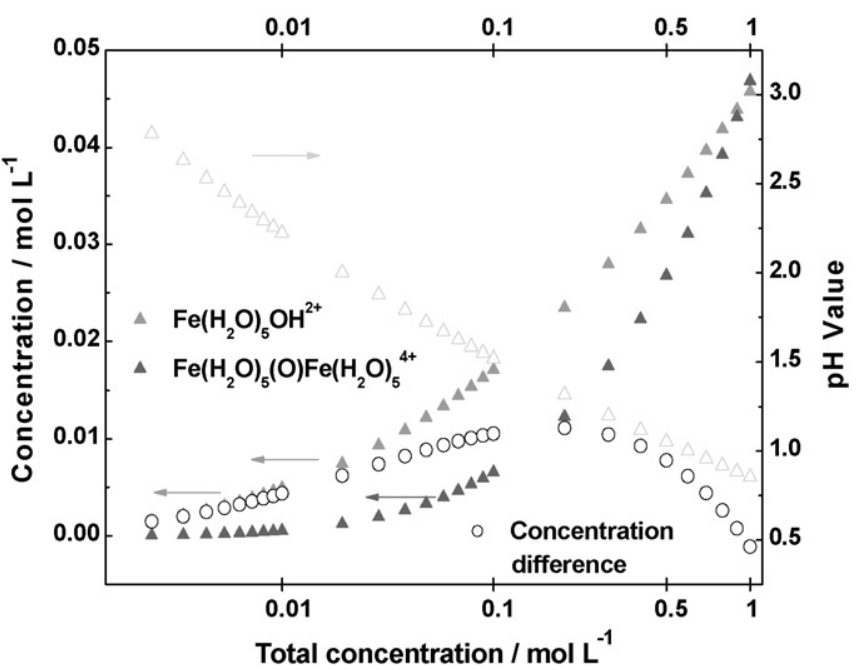

Fig. 1. Distribution of $\mathrm{Fe}$ species and $\mathrm{pH}$ values as a function of $\mathrm{Fe}$ total concentration.

concentration of $\mathrm{Fe}\left(\mathrm{H}_{2} \mathrm{O}\right)_{5}(\mathrm{O}) \mathrm{Fe}\left(\mathrm{H}_{2} \mathrm{O}\right)_{5}{ }^{4+}$ can lead to a higher $\mathrm{Fe}$ exchange degree. As shown in Fig. 1, the maximum concentration difference between $\mathrm{Fe}\left(\mathrm{H}_{2} \mathrm{O}\right)_{5}(\mathrm{OH})^{2+}$ and $\mathrm{Fe}\left(\mathrm{H}_{2} \mathrm{O}\right)_{5}(\mathrm{O}) \mathrm{Fe}\left(\mathrm{H}_{2} \mathrm{O}\right)_{5}{ }^{4+}$ seems to occur at total $\left[\mathrm{Fe}^{3+}\right]=0.05-0.4 \mathrm{M}$, while $\mathrm{Fe}\left(\mathrm{H}_{2} \mathrm{O}\right)_{5}(\mathrm{O})-$ $\mathrm{Fe}\left(\mathrm{H}_{2} \mathrm{O}\right)_{5}{ }^{4+}$ starts to appear at $\left[\mathrm{Fe}^{3+}\right]=0.01 \mathrm{M}$ and exists with a considerable amount at $\left[\mathrm{Fe}^{3+}\right]=0.1 \mathrm{M}$. So, considering the stability of the parent USY zeolite under acid conditions ( $\mathrm{pH}>1.5$ ), we chose $0.05 \mathrm{M} \mathrm{FeCl}_{3}$ solution with $\mathrm{pH} \sim 1.8$ in this research for exchange, and achieved a higher $\mathrm{Fe}$ loading $(\mathrm{Fe} / \mathrm{Al}=0.44)$ in $\mathrm{Fe}(\mathrm{III})$-USY. However, the steric hindrance may be the main reason that $\mathrm{Fe}(\mathrm{III})-$ ZSM-5 can only load small amounts of $\mathrm{Fe}(\mathrm{III})(\mathrm{Fe} / \mathrm{Al}=0.04)$ because both $\mathrm{Fe}\left(\mathrm{H}_{2} \mathrm{O}\right)_{6}{ }^{3+}$ and $\mathrm{Fe}\left(\mathrm{H}_{2} \mathrm{O}\right)_{5}(\mathrm{OH})^{2+}$ ions $(0.68 \mathrm{~nm})$ are much larger than ZSM-5 channel size $\left(\left[\begin{array}{lll}1 & 0 & 0\end{array}\right] 0.51 \times 0.55 \mathrm{~nm} \leftrightarrow\left[\begin{array}{lll}0 & 1 & 0\end{array}\right]\right.$ $0.53 \times 0.56 \mathrm{~nm})$.

In ZSM-5 we find much higher $\mathrm{Fe}(\mathrm{II})$ loading than $\mathrm{Fe}$ (III) loading $(\mathrm{Fe} / \mathrm{Al}=0.24$ in $\mathrm{Fe}(\mathrm{II})-\mathrm{ZSM}-5$ vs. 0.04 in $\mathrm{Fe}(\mathrm{III})-\mathrm{ZSM}-5)$. This result indicates that something happens to the hydrated $\mathrm{Fe}\left(\mathrm{H}_{2} \mathrm{O}\right)_{6}{ }^{2+}$ during the exchange. One possible process is dissociation of $\mathrm{Fe}^{2+}$ $\mathrm{H}_{2} \mathrm{O}$ ligand bonds, so $\mathrm{Fe}\left(\mathrm{H}_{2} \mathrm{O}\right)_{6}{ }^{2+}$ loses some water and the size is reduced, which thus promotes the ion exchange. The dissociation may be further driven by the increase of electrostatic interactions of smaller ferrous ions (less hydrated) with the zeolite matrix at the zeolite channel mouth [26]. In contrast, it is unlikely for $\mathrm{Fe}\left(\mathrm{H}_{2} \mathrm{O}\right)_{6}{ }^{3+}$ and $\mathrm{Fe}\left(\mathrm{H}_{2} \mathrm{O}\right)_{5}(\mathrm{OH})^{2+}$ to break the $\mathrm{Fe}^{3+}-\mathrm{H}_{2} \mathrm{O}$ bond to lose water and reduce the ion size for exchange, because the hydrated enthalpy of ferric ions ( $c a .4500 \mathrm{~kJ} \mathrm{~mol}^{-1}$ ) is much greater than that of ferrous ions (ca. $2000 \mathrm{~kJ} \mathrm{~mol}^{-1}$ ) [27] at room temperature. Therefore, in order for researchers to make fully-exchanged Fe(III)ZSM-5, heating is required to facilitate the $\mathrm{Fe}^{3+}-\mathrm{H}_{2} \mathrm{O}$ bond dissociation, as reported by Melián-Cabrera et al. [28]. However, heating may promote the deep hydrolysis of ferric ions and may result in formation of the iron oxide on the outer surface of zeolite to block some channels.

As shown in Fig. 2, the framework of parent zeolites is well preserved after ion exchange and subsequent calcination. XRD patterns of $\mathrm{Fe}(\mathrm{II})-\mathrm{ZSM}-5$ and $\mathrm{Fe}(\mathrm{III})-\mathrm{ZSM}-5$ are the same, with the diffraction peaks being characteristic of the MFI structure [29]. Similarly, the XRD patterns of all other Fe-zeolites show typical diffraction peaks corresponding to the characteristic FAU structure [29] except for Fe(III)-NaY, whose XRD pattern has much weaker characteristic diffraction peaks at $2 \theta>10^{\circ}$. This difference may indicate some deterioration of FAU structure after the ion exchange and subsequent calcination, similar to that happening during 


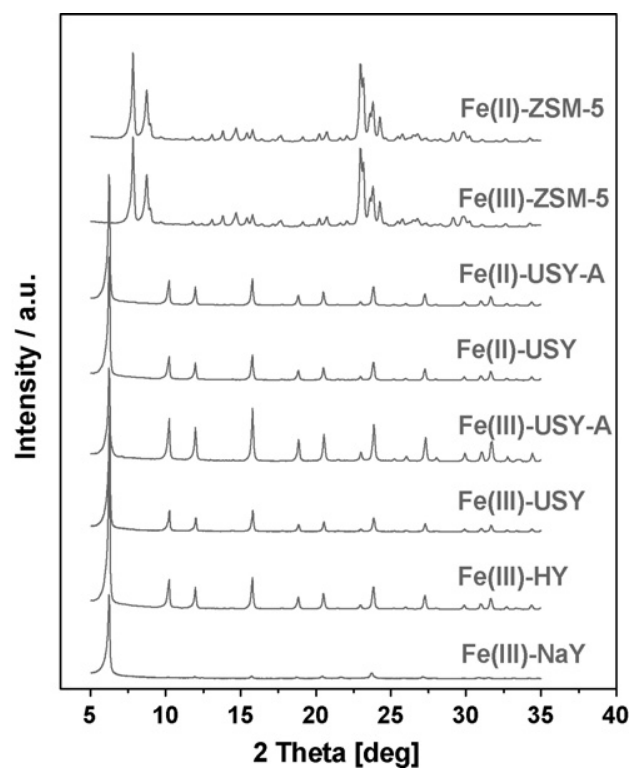

Fig. 2. XRD patterns of as-prepared iron-zeolites.

$\left(\mathrm{NH}_{4}\right)_{2} \mathrm{SO}_{4}$ ion exchange of $\mathrm{Na}-\mathrm{Y}$ [30]. In addition, no obvious diffraction peaks corresponding to crystallized $\mathrm{Fe}_{x} \mathrm{O}_{y}$ can be observed at the Fe loading up to 5-6 wt\%, suggesting the good dispersion of iron species on the internal/external surface and the limited segregation of $\mathrm{Fe}_{x} \mathrm{O}_{y}$ nanoparticles.

\subsection{Fe species formed in zeolite}

\subsubsection{UV-vis DR spectra of Fe-zeolites}

The nature and distribution of iron species in these Fe-zeolites can be identified by various techniques. One commonly used one is UV-vis DR spectroscopy. As shown in Fig. 3, Fe-zeolites exhibit strong absorbance in $200-800 \mathrm{~nm}$, revealing the existence of various ferric ion species in these Fe-zeolite samples. After suitable spectral deconvolution for ion-exchanged Fe(III)-USY (Fig. 3A), several characteristic UV-vis absorption bands can be extracted and attributed to specific ferric ion species. In general, two bands at 215 and $285 \mathrm{~nm}$ are assigned to isolated Fe(III) in tetrahedral and octahedral coordination [31,32], respectively. These two bands are also assigned by Pirngruber et al. [33] to ferric ion dimers considering that the antiferromagnetic coupling is weak. Two bands located between 300 and $400 \mathrm{~nm}$ (at 335 and $385 \mathrm{~nm}$ ) are ascribed to oligonuclear $\mathrm{Fe}(\mathrm{III})_{x} \mathrm{O}_{y}$ clusters in zeolite internal/ external surfaces [16], and another two bands at above $400 \mathrm{~nm}$ (at 460 and $550 \mathrm{~nm}$ ) are attributed to $\mathrm{Fe}_{2} \mathrm{O}_{3}$ nanoparticles $(\sim 1 \mathrm{~nm})$ at the external surface of the zeolite crystal [34].

Spectral comparison of three Fe(III)-USY (exchanged, calcined and acid-treated, Fig. $3 \mathrm{~A}-\mathrm{C}$ and Table 2 ) reveals that (i) the two bands corresponding to isolated Fe(III) are strongest in all three cases, showing high population of isolated Fe(III) in the zeolite; (ii) after calcination (Fig. 3B), two bands corresponding to the oligonuclear $\mathrm{Fe}(\mathrm{III})_{x} \mathrm{O}_{y}$ clusters become a bit stronger, while those bands to $\mathrm{Fe}_{2} \mathrm{O}_{3}$ nanoparticles are nearly unchanged, indicating slightly preferential formation of oligonuclear $\mathrm{Fe}(\mathrm{III})_{x} \mathrm{O}_{y}$ clusters upon calcination; (iii) acid treatment of calcined Fe(III)-USY dislodges $\mathrm{Fe}_{2} \mathrm{O}_{3}$ nanoparticles as well as isolated $\mathrm{Fe}(\mathrm{III}), \mathrm{Fe}(\mathrm{III})_{x} \mathrm{O}_{y}$ clusters and $\mathrm{Al}$ species, as clearly shown by the increase of $\mathrm{Si} / \mathrm{Al}$ ratio, the lower Fe loading (Table 1 ) and the reduction of each iron species (Table 2).

On the other hand, the UV-vis spectra of Fe(II)-USY after ion exchange (dried at $353 \mathrm{~K}$ overnight) and calcination $(873 \mathrm{~K}, 4 \mathrm{~h})$ show the existence of a considerable amount of isolated $\mathrm{Fe}(\mathrm{III})$, oligonuclear $\mathrm{Fe}(\mathrm{III})_{x} \mathrm{O}_{y}$ clusters and $\mathrm{Fe}_{2} \mathrm{O}_{3}$ nanoparticles. The oxidation of $\mathrm{Fe}(\mathrm{II})$ to $\mathrm{Fe}(\mathrm{III})$ presumably occurs after exchange, perhaps during drying and/or calcination. In particular, calcination gives many more oligonuclear $\mathrm{Fe}(\mathrm{III})_{x} \mathrm{O}_{y}$ clusters and $\mathrm{Fe}_{2} \mathrm{O}_{3}$ nanoparticles (Fig. 3E and Table 2). This is in sharp contrast with the fact that Fe(III)-USY exhibits the similar UV-vis spectra before and after calcination, which reflects the higher thermal stability of iron species in Fe(III)-USY. In addition, calcined Fe(III)-HY and $\mathrm{Fe}$ (III)-NaY samples (Fig. 3G-H and Table 2) were found to contain a considerable amount of isolated $\mathrm{Fe}(\mathrm{III})$ ions, oligonuclear $\mathrm{Fe}(\mathrm{III})_{x} \mathrm{O}_{y}$ clusters and $\mathrm{Fe}_{2} \mathrm{O}_{3}$ nanoparticles, while calcined $\mathrm{Fe}(\mathrm{III})-\mathrm{NaY}$ contains more $\mathrm{Fe}_{2} \mathrm{O}_{3}$ nanoparticles.

\subsubsection{TEM images and $\mathrm{H}_{2}$ TPR of Fe-zeolites}

In line with the results of UV-vis spectra, the TEM image (Fig. 4A) has indicated that iron oxides/clusters in ion-exchanged $\mathrm{Fe}(\mathrm{III})$-USY are so very small $(<1 \mathrm{~nm})$ that they are hard to observe. Such iron oxides/clusters probably come from the aggregation and dehydration of iron-containing species on the zeolite surface during the drying process. After calcination, larger $\mathrm{Fe}_{2} \mathrm{O}_{3}$ nanoparticles (1-4 nm) can be observed (Fig. 4B), suggesting the aggregation of small iron oxides/clusters and isolated $\mathrm{Fe}(\mathrm{III})$ species upon calcination. However, such an aggregation of small iron oxides from $<1$ to $1-4 \mathrm{~nm}$ does not result in any obvious change in the intensity of corresponding UV-vis bands, meaning that the formed $\mathrm{Fe}_{2} \mathrm{O}_{3}$ nanoparticles (1-4 nm) contribute relatively little weight. After acid treatment (Fe(III)-USY-A), a majority of larger $\mathrm{Fe}_{2} \mathrm{O}_{3}$ nanoparticles (1-4 nm) is dislodged, with fewer small iron oxides left (Fig. 4C). The black spots in the TEM image of calcined Fe(III)-HY (Fig. 4D) are similar to those of calcined Fe(III)USY both in darkness and spot size. However, the TEM image of calcined $\mathrm{Fe}(\mathrm{III})-\mathrm{NaY}$ shows much larger $\mathrm{Fe}_{2} \mathrm{O}_{3}$ nanoparticles with much darker background, probably due to more $\mathrm{Fe}_{2} \mathrm{O}_{3}$ nanoparticles and to some deterioration of the FAU structure.

The $\mathrm{H}_{2}$-TPR profiles of Fe-zeolites reveal the existence of reducible $\mathrm{Fe}_{2} \mathrm{O}_{3}$ nanoparticles in some cases. As shown in Fig. 5, $\mathrm{H}_{2}$ consumption (e.g. Fe reduction) starts at $400-450 \mathrm{~K}$ and continues to over $1100 \mathrm{~K}$. Previous investigations $[3,13,35,36]$ demonstrate

Table 2

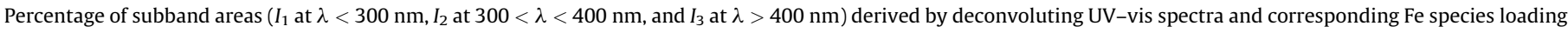

\begin{tabular}{|c|c|c|c|c|c|c|}
\hline Samples & $I_{1}^{\mathrm{a}}(\%)$ & $I_{2}{ }^{\mathrm{a}}(\%)$ & $I_{3}{ }^{\mathrm{a}}(\%)$ & Isolated $^{\mathrm{b}}(\%)$ & Oligonuclear $^{\mathrm{b}}(\%)$ & Nanoparticles $^{\mathrm{b}}(\%)$ \\
\hline Fe(III)-USY ion exchanged & 54.2 & 34.1 & 11.7 & 1.83 & 1.15 & 0.39 \\
\hline $\mathrm{Fe}(\mathrm{III})-\mathrm{USY}$ & 50.4 & 38.3 & 11.4 & 1.70 & 1.29 & 0.39 \\
\hline $\mathrm{Fe}(\mathrm{III})-\mathrm{USY}-\mathrm{A}$ & 57.9 & 33.8 & 8.3 & 1.19 & 0.69 & 0.17 \\
\hline Fe(II)-USY ion exchanged & 59.3 & 31.2 & 9.5 & 1.65 & 0.87 & 0.27 \\
\hline $\mathrm{Fe}(\mathrm{II})-\mathrm{USY}$ & 44.3 & 35.0 & 20.7 & 1.23 & 0.98 & 0.58 \\
\hline $\mathrm{Fe}(\mathrm{II})-\mathrm{USY}-\mathrm{A}$ & 53.0 & 35.5 & 11.5 & 1.04 & 0.71 & 0.23 \\
\hline $\mathrm{Fe}(\mathrm{III})-\mathrm{HY}$ & 51.9 & 38.4 & 9.7 & 2.82 & 2.08 & 0.53 \\
\hline $\mathrm{Fe}(\mathrm{III})-\mathrm{NaY}$ & 51.8 & 35.1 & 13.1 & 3.19 & 2.16 & 0.81 \\
\hline
\end{tabular}

\footnotetext{
a Calculated from the data in Fig. 3.
}

b In wt\%. 

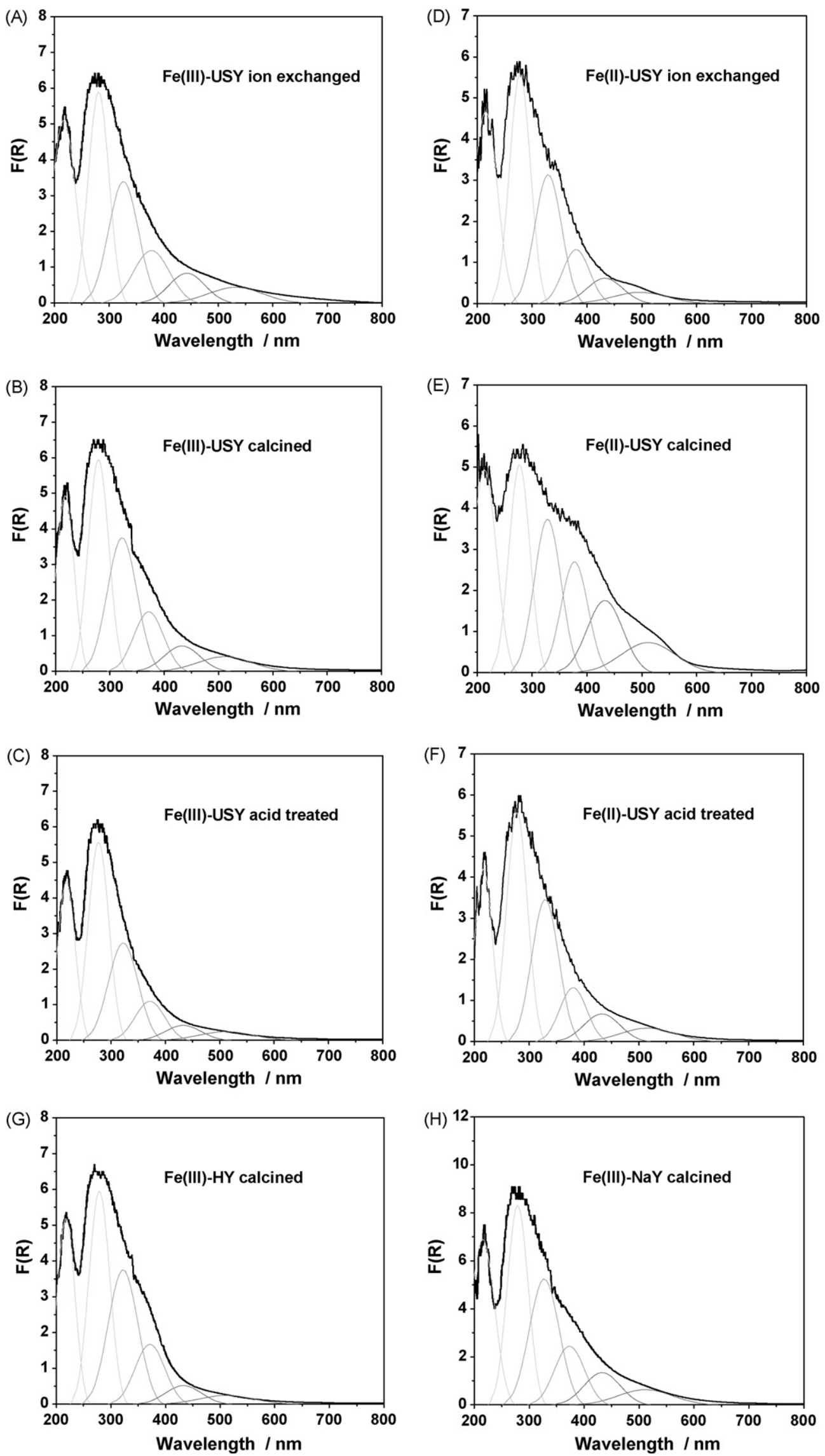

Fig. 3. UV-vis spectra of Fe(III)-USY (A-C), Fe(II)-USY (D-F), Fe(III)-HY (G) and Fe(III)-NaY (H). 

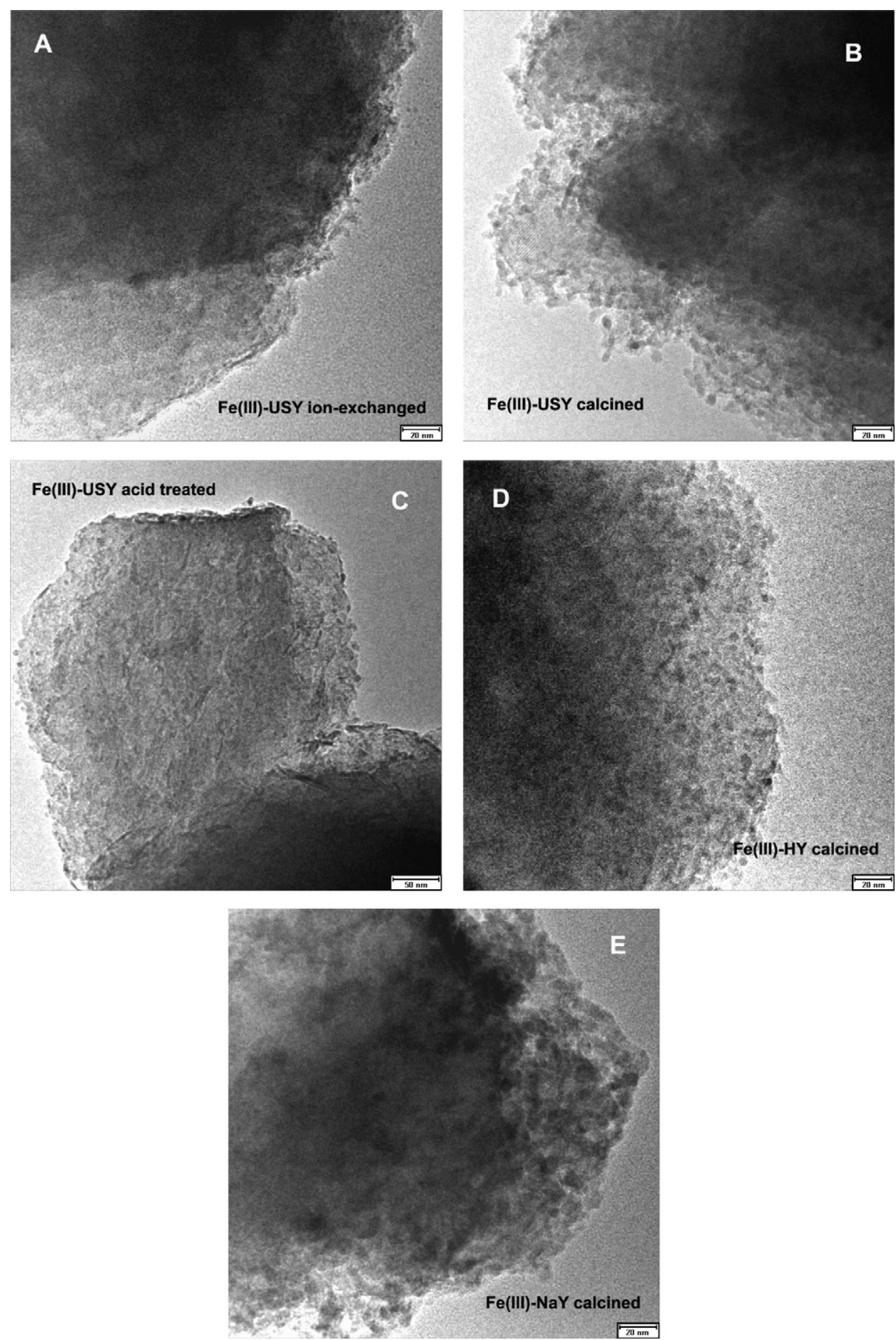

Fig. 4. TEM images of ion-exchanged Fe(III)-USY (A), calcined Fe(III)-USY (B), acid-treated Fe(III)-USY (C), calcined Fe(III)-HY (D) and calcined Fe(III)-NaY (E).

that (i) $\mathrm{H}_{2}$ consumption up to $750 \mathrm{~K}$ corresponds to reduction of $\mathrm{Fe}(\mathrm{III})$ to $\mathrm{Fe}(\mathrm{II})$ (isolated, oligonuclear and nanoparticle), (ii) reaction in $750-1000 \mathrm{~K}$ is due to reduction of $\mathrm{FeO}$ (from nanoparticles) to $\mathrm{Fe}^{0}$, and (iii) $\mathrm{H}_{2}$ consumption over $1000 \mathrm{~K}$ is due to reduction of $\mathrm{Fe}(\mathrm{II})$ to $\mathrm{Fe}^{0}$ in oligonuclear/isolated form, with collapse of the zeolite framework. Compared with acid-treated $\mathrm{Fe}$ (III)-USY-A, the calcined Fe(III)-USY has an extra reduction bump at $\sim 900 \mathrm{~K}$. This means that the latter contains more reducible $\mathrm{Fe}_{2} \mathrm{O}_{3}$ nanoparticles, in agreement with observations from UV-vis spectra and TEM images. In particular, the $\mathrm{H}_{2}$-TPR profiles of $\mathrm{Fe}(\mathrm{II})-$
USY and $\mathrm{Fe}(\mathrm{III})-\mathrm{NaY}$ show a broad band in $800-1000 \mathrm{~K}$, indicating the existence of much more reducible $\mathrm{Fe}_{2} \mathrm{O}_{3}$ nanoparticles, in line with the UV-vis and TEM observations.

\subsubsection{FTIR spectra of NO adsorbed on Fe-zeolites}

Fig. 6 presents the time-dependent FTIR spectra of NO adsorbed on some iron-zeolites at room temperature. In the normal nitrosyl region (1700-1970 $\mathrm{cm}^{-1}$ ) [37], two very weak bands at 1910 and $1850 \mathrm{~cm}^{-1}$ are observed, without significant change with time in intensity for the ion-exchanged Fe(III)-USY (bottom lines, Fig. 6A). 


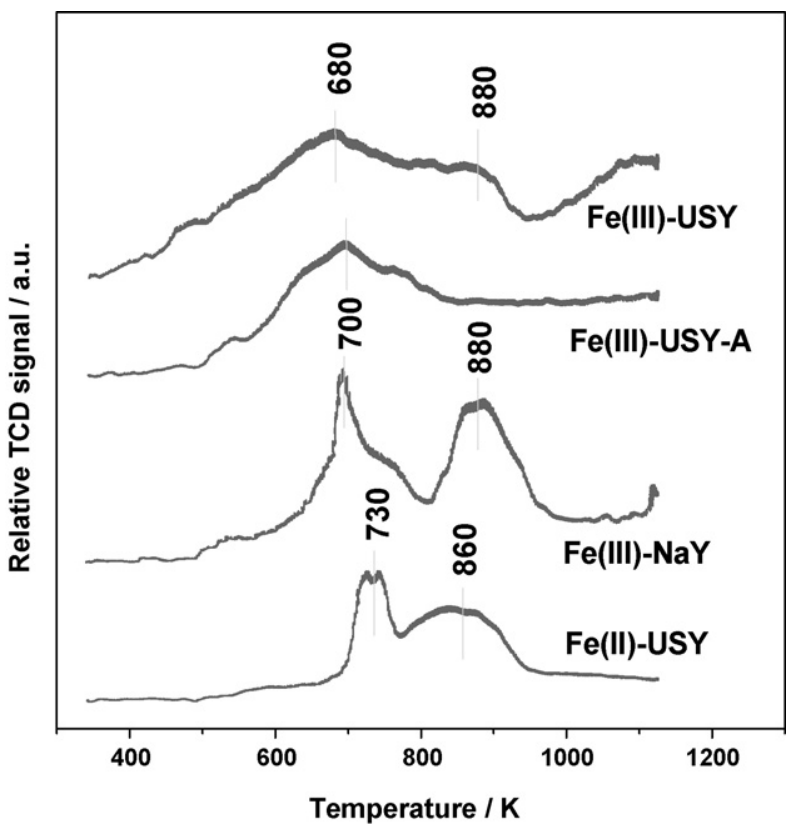

Fig. 5. $\mathrm{H}_{2}$-TPR profiles of selected Fe-zeolite samples.

The band at $1850 \mathrm{~cm}^{-1}$ is attributed to the mononitrosyl group while that at $1910 \mathrm{~cm}^{-1}$ is attributed to dinitrosyl group on isolated iron sites in zeolites [38-40]. Some other weak peaks at $1550,1425,1360,1230,1130$ and $1100 \mathrm{~cm}^{-1}$ are due to nitrites/ nitrates oxidized from NO and stored on the surface [37], which slightly increase in intensity with the adsorption time. The strongest band at $1715 \mathrm{~cm}^{-1}$, obviously intensifying with the adsorption time, in our opinion, could be assigned to the mononitrosyl group on dinuclear oxygen-bridged Fe ions (discussed in Section 3.3.5), while a similar band at $1700-1750 \mathrm{~cm}^{-1}$ was assigned to mononitrosyl on $\mathrm{Fe}(\mathrm{II})$ clusters in $\mathrm{Fe} / \mathrm{ZrO}_{2}$ [41] and $\mathrm{Fe} / \mathrm{SnO}_{2}$ [42], and on $\mathrm{Fe}^{n+}$ clusters in $\mathrm{Fe} / \mathrm{Al}_{2} \mathrm{O}_{3}$ and $\mathrm{Fe} / \mathrm{TiO}_{2}$ [43]. Surprisingly, such an intense band almost completely disappears on calcined $\mathrm{Fe}(\mathrm{III})-\mathrm{USY}$, indicating the disappearance of the dinuclear oxygen bridged Fe ions. Note that peaks at 1550, 1230 and $1130 \mathrm{~cm}^{-1}$ due to nitrites/nitrates become more intense with the adsorption time. This shows that adsorption of $\mathrm{NO}$ on calcined $\mathrm{Fe}(\mathrm{III})$-USY is mainly a process involving oxidation of $\mathrm{NO}$ and storage as nitrites/nitrates. More surprisingly, acid treatment/ calcination brings back the dinuclear oxygen-bridged Fe ions, as indicated by the reappearance of the intense band at $1715 \mathrm{~cm}^{-1}$ (top lines, Fig. 6A).

In the case of ion-exchanged Fe(II)-USY, NO is adsorbed in some other way. As shown in Fig. 6B, although weak bands at 1910, 1850, and $1765 \mathrm{~cm}^{-1}$ (corresponding to mono- and di-nitrosyl groups) are also observed, the strongest bands are located at 1360 and $1400 \mathrm{~cm}^{-1}$, then shift to 1340 and $1425 \mathrm{~cm}^{-1}$ over the calcined $\mathrm{Fe}(\mathrm{II})-\mathrm{USY}$, corresponding to various nitrates [37]. The formation of nitrates is probably a result of $\mathrm{NO}$ oxidation over $\mathrm{Fe}(\mathrm{II}, \mathrm{III})$ mixed oxide clusters/nanoparticles. We believe that the exchanged Fe(II) ions are partly oxidized to $\mathrm{Fe}$ (III) ions in isolated, cluster, and particle form during drying and calcination. After acid treatment, the band at $1715 \mathrm{~cm}^{-1}$ becomes obvious, indicating the formation of the dinuclear oxygen bridged Fe ions, as in the case of acidtreated Fe(III)-USY.

The FTIR spectra of NO adsorbed on Fe(III)-HY (Fig. 6C) indicate that NO adsorbs over ion-exchanged and calcined Fe(III)-HY in a way similar to that over Fe(III)-USY. The predominant adsorption occurs over the dinuclear oxygen-bridged Fe ions in the Fe(III)exchanged sample while such species disappear after calcination.
In the case of $\mathrm{Fe}(\mathrm{III})-\mathrm{NaY}$ (Fig. 6D), the exchanged and calcined samples show the similar NO adsorption behavior, i.e. adsorption at isolated Fe(III) sites (bands at 1910, 1850, 1765 and $1715 \mathrm{~cm}^{-1}$ ) [38-40], and formation of nitrates (broad peak at $1425 \mathrm{~cm}^{-1}$ ). However, this behavior is much different from that over Fe(III)-USY and $\mathrm{Fe}(\mathrm{III})-\mathrm{HY}$, probably related to deterioration of the FAU structure, as shown by the XRD and TEM images.

\subsection{4. ${ }^{27}$ Al MAS-NMR spectra of Fe-zeolites}

The ${ }^{27} \mathrm{Al}$ MAS-NMR spectra in Fig. 7 provide useful information regarding the transformation of tetrahedral and octahedral $\mathrm{Al}$ species during various treatments of Fe(III)-USY sample, and show the formation of various forms of iron species as well. As seen in the spectrum for the parent $\mathrm{H}$-USY, there are two ${ }^{27} \mathrm{Al}$ resonances, a strong one at $55 \mathrm{ppm}$ and a weak one at $-5 \mathrm{ppm}$, corresponding to two kinds of $\mathrm{Al}$ species in USY zeolite. In general, the resonance at $55 \mathrm{ppm}$ is attributed to tetrahedrally coordinated $\mathrm{Al}\left(\mathrm{Al}^{\mathrm{IV}}\right)$ in the zeolite lattice [44] and that at -5 to $0 \mathrm{ppm}$ is due to frameworkconnected octahedral $\mathrm{Al}$ species $\left(\mathrm{Al}^{\mathrm{VI}}\right)$ [45]. After wet ion exchange/ drying, the resonance peak at $55 \mathrm{ppm}$ is narrower, while the weak peak at $-5 \mathrm{ppm}$ corresponding to $\mathrm{Al}^{\mathrm{VI}}$ does not change. After calcination, however, the peak at $-5 \mathrm{ppm}$ relevant to $\mathrm{Al}^{\mathrm{VI}}$ species becomes much stronger, indicating the transform of lattice $\mathrm{Al}^{\mathrm{IV}}$ to extra-lattice $\mathrm{Al}^{\mathrm{VI}}$ during calcination. Further acid treatment of calcined $\mathrm{Fe}$ (III)-USY weakens the responses both at 55 and $-5 \mathrm{ppm}$, with the latter weakened much more, showing that more extra-lattice $\mathrm{Al}^{\mathrm{VI}}$ species are dislodged.

\subsubsection{Transformation of iron species in Fe(III)-USY}

Based on the above observations, we draw a schematic diagram (Fig. 8) to outline the formation of various iron species and the transformation of $\mathrm{Al}$ species in sample $\mathrm{Fe}(\mathrm{III})$-USY during exchange/drying, calcination and acid treatment. After ion exchange (Step 1), most protons are substituted with iron species, to form isolated $\mathrm{Fe}(\mathrm{III})$ ions (species a, normally with some coordinated $\mathrm{H}_{2} \mathrm{O}$ but not shown here), dinuclear oxygen-bridged Fe ions (species b, coordinated $\mathrm{H}_{2} \mathrm{O}$ or $\mathrm{OH}$ not shown), oligonuclear $\mathrm{Fe}(\mathrm{III})_{x} \mathrm{O}_{y}$ clusters (species $\mathbf{c}$ ) and $\mathrm{Fe}_{2} \mathrm{O}_{3}$ nanoparticles (not shown in the figure). The existence of dinuclear oxygen-bridged Fe species has been very recently reported by Nam and co-workers for the solid-exchange Fe-ZSM-5 catalysts with $\mathrm{Fe} / \mathrm{Al}>0.2$ [46]. In this process, the iron species replace almost all protons and are bound to the lattice. Meanwhile, the lattice $\mathrm{Al}^{\mathrm{IV}}$ species remain unchanged, as suggested by the ${ }^{27} \mathrm{Al}$ NMR spectrum.

The calcination at $873 \mathrm{~K}$ (Step 2), in our opinion, brings about a few new species, such as isolated $\mathrm{Al}^{\mathrm{VI}}-\mathrm{O}-\mathrm{Fe}(\mathrm{III})$ (not shown here), $\mathrm{Al}^{\mathrm{IV}}-\mathrm{O}-\mathrm{Fe}(\mathrm{III})_{m} \mathrm{O}_{n}$ complex (species d), and $\mathrm{Al}^{\mathrm{VI}}-\mathrm{O}-\mathrm{Fe}(\mathrm{III})_{p} \mathrm{O}_{q}$ complex (species e). As the dinuclear oxygen bridged Fe ions are now transformed to larger oligonuclear $\mathrm{Fe}(\mathrm{III})_{m} \mathrm{O}_{n}$ clusters (from

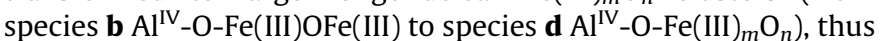
calcined $\mathrm{Fe}$ (III)-USY does not show the characteristic NO adsorption band at $1715 \mathrm{~cm}^{-1}$. In addition, the transformation of tetrahedral $\mathrm{Al}^{\mathrm{IV}}$ to octahedral $\mathrm{Al}^{\mathrm{VI}}$ is also in line with the intense

${ }^{27} \mathrm{Al}$ NMR resonance peak at $-5 \mathrm{ppm}$.

After acid treatment at room temperature and calcination at $873 \mathrm{~K}$ (Step 3), some $\mathrm{Al}^{\mathrm{VI}}$, isolated $\mathrm{Fe}(\mathrm{III}), \mathrm{Fe}(\mathrm{III})_{p} \mathrm{O}_{q}$ clusters and most $\mathrm{Fe}_{2} \mathrm{O}_{3}$ nanoparticles are removed from the zeolite surface by dissolution. The leaching of $\mathrm{Fe}$ and $\mathrm{Al}$ from the zeolite is supported by element analysis (Table 1). Based on UV-vis spectra (Fig. 3), TEM images (Fig. 4) and ${ }^{27} \mathrm{Al}$ NMR spectra (Fig. 7), we presume that the acid treatment induces a series of reactions, such as dissolution of $\mathrm{Al}^{\mathrm{VI}}$ and removal of oligonuclear $\mathrm{Fe}(\mathrm{III})_{p} \mathrm{O}_{q}$ (from species e to f). Another possible reaction is the re-deposition of leached $\mathrm{Fe}^{3+}$ ions to form species $\mathbf{a}$ and $\mathbf{b}$ as there is a large enough amount of $\mathrm{Fe}^{3+}$ in the solution. Therefore, the dinuclear oxygen-bridged Fe ions 

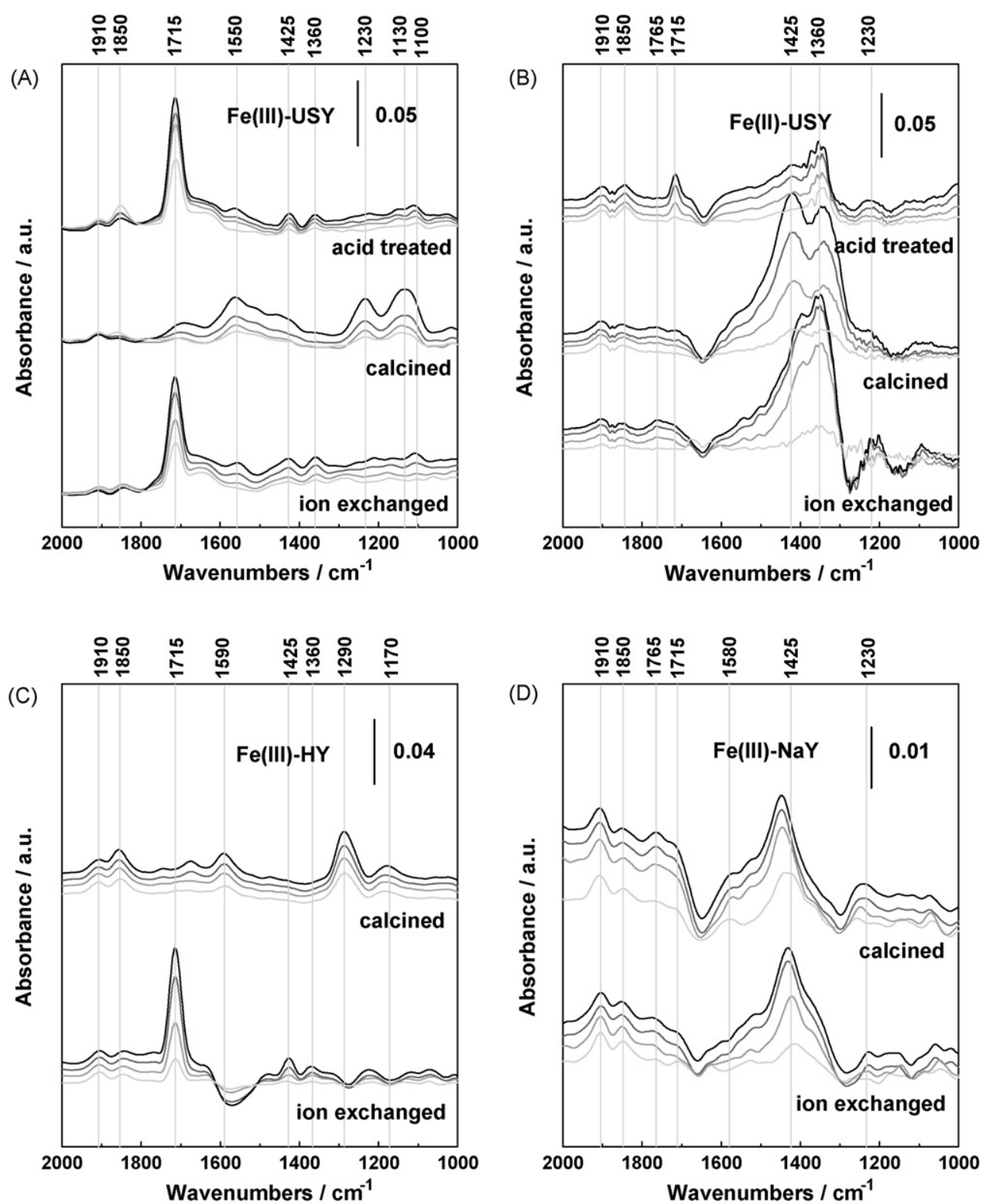

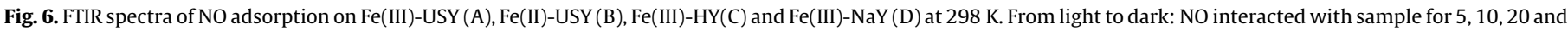
$30 \mathrm{~min}$.

(species b) are re-generated and can adsorb NO with the characteristic IR absorption at $1715 \mathrm{~cm}^{-1}$ (Fig. 6A).

\subsection{Catalytic performances of Fe-zeolites}

The temperature dependence of steady-state $\mathrm{N}_{2} \mathrm{O}$ decomposition over Fe-USY and Fe-ZSM-5 catalysts is shown in Fig. 9A. Fe(III)USY exhibits the highest $\mathrm{N}_{2} \mathrm{O}$ decomposition activity while $\mathrm{Fe}(\mathrm{III})-$ ZSM-5 gives the lowest activity, which can be first ascribed to the difference in $\mathrm{Fe}(\mathrm{III})$ loading. As listed in Table 1, Fe(III)-USY has much higher $\mathrm{Fe}(\mathrm{III})$ loading than in $\mathrm{Fe}(\mathrm{III})-\mathrm{ZSM}-5$ (3.38 vs. $0.30 \mathrm{wt} \%$ ) and thus possesses proportionally more active $\mathrm{Fe}$ species. Due to the same reason, both Fe(II)-USY (2.79 wt\% Fe) and $\mathrm{Fe}(\mathrm{II})-\mathrm{ZSM}-5$ (1.81 wt\% Fe) have activity lower than that of $\mathrm{Fe}(\mathrm{III})-\mathrm{USY}$ but higher than that of Fe(III)-ZSM-5. The figure also shows that $\mathrm{Fe}(\mathrm{III})-\mathrm{USY}$ catalyst starts $\mathrm{N}_{2} \mathrm{O}$ decomposition at ca. $600 \mathrm{~K}$, and the $50 \%$ and $100 \% \mathrm{~N}_{2} \mathrm{O}$ conversion occurs at 670 and $750 \mathrm{~K}$, respectively. This activity for $\mathrm{N}_{2} \mathrm{O}$ decomposition is comparable with or even better than the best iron-zeolite catalysts reported elsewhere, e.g. Fe-Ferrierite [13,28]. Compared with ferrierite, much cheaper USY appears to be a more economical zeolite-hosting iron species for $\mathrm{N}_{2} \mathrm{O}$ decomposition.

The Fe loading is not the only factor that determines catalytic activity for $\mathrm{N}_{2} \mathrm{O}$ decomposition. As shown in Fig. 9B, Fe(III)-USY and $\mathrm{Fe}$ (III)-USY-A perform very similarly in term of $\mathrm{N}_{2} \mathrm{O}$ conversion at the same temperature. However, their Fe loadings are quite different, being $3.38 \mathrm{wt} \%$ in $\mathrm{Fe}(\mathrm{III})-\mathrm{USY}$ and $2.06 \mathrm{wt} \%$ in the acidtreated Fe(III)-USY-A. Similarly, Fe(III)-HY has 5.43 wt\% Fe(III), yet it only shows an activity a bit higher than Fe(III)-USY and Fe(III)USY-A. To the contrary, Fe(III)-NaY has the highest Fe(III) loading (6.16 wt\%), but exhibits a much lower activity (Fig. 8B). Similar finding has been reported by Segawa and co-workers [47] that low Fe loading in Fe-MFI exhibited a rather high $\mathrm{N}_{2} \mathrm{O}$ conversion. These observations suggest that the active $\mathrm{Fe}$ species is the other important factor that determines the catalytic activity for $\mathrm{N}_{2} \mathrm{O}$ decomposition.

It has been proposed that both isolated $\mathrm{Fe}(\mathrm{III})$ species and oligonuclear $\mathrm{Fe}(\mathrm{III})_{x} \mathrm{O}_{y}$ cluster are active, but the latter is more 


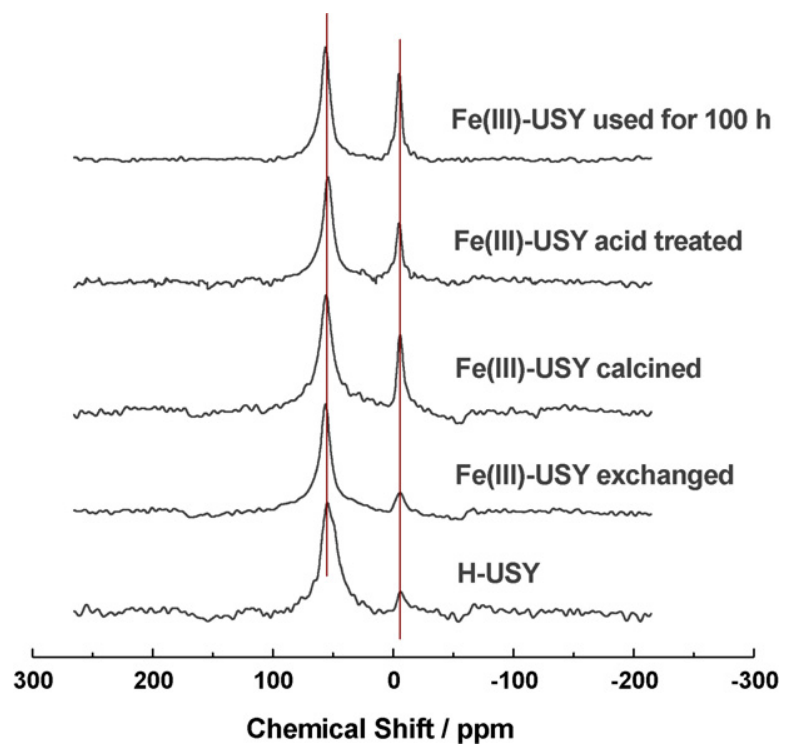

Fig. 7. ${ }^{27} \mathrm{Al}$ MAS-NMR spectra of parent H-USY, ion exchanged Fe(III)-USY, calcined $\mathrm{Fe}(\mathrm{III})-\mathrm{USY}$, acid-treated Fe(III)-USY-t and Fe(III)-USY used for $100 \mathrm{~h}$.

active for $\mathrm{N}_{2} \mathrm{O}$ decomposition $[6,10,48]$. Based on the current research, however, it is difficult to judge which one is more active. We noted that Fe(III)-USY, Fe(III)-USY-A and Fe(III)-HY have very similar activity values, but the fractionated isolated and oligonuclear Fe(III) species vary in loading from 1.13 to $2.82 \mathrm{wt} \%$ and from 0.69 to $2.08 \mathrm{wt} \%$ (Table 2), respectively. Thus we cannot simply say that isolated or oligonuclear Fe(III) sites are more active than the other, but we could infer that only a small fraction of isolated or oligonuclear $\mathrm{Fe}(\mathrm{III})$ sites are active for $\mathrm{N}_{2} \mathrm{O}$ decomposition.

The site accessibility is probably the other important factor that determines the activity contribution of isolated or oligonuclear $\mathrm{Fe}(\mathrm{III})$ sites. For example, the iron sites near the channel mouth are more easily accessed by $\mathrm{N}_{2} \mathrm{O}$ than those sitting in sodalite cavities, which have highly hindered access to the $\mathrm{N}_{2} \mathrm{O}$ molecule and thus show a higher apparent activity. The accessibility is also affected by the presence of $\mathrm{Fe}_{2} \mathrm{O}_{3}$ nanoparticles. Once $\mathrm{Fe}_{2} \mathrm{O}_{3}$ nanoparticles block the channel mouth, the channel is not accessible to $\mathrm{N}_{2} \mathrm{O}$ and does not contribute to the $\mathrm{N}_{2} \mathrm{O}$ decomposition. This may be the reason why $\mathrm{Fe}(\mathrm{III})$-USY-A has an activity value similar to those of Fe(III)-USY and Fe(III)-HY. The latter two have much higher isolated/oligonuclear $\mathrm{Fe}(\mathrm{III})$ sites, but they also contain more $\mathrm{Fe}_{2} \mathrm{O}_{3}$ nanoparticles (TEM in Fig. 4 and Table 2), so their total accessible active $\mathrm{Fe}(\mathrm{III})$ sites may be similar to those of $\mathrm{Fe}$ (III)-USY-A. Similarly, Fe(II)-USY contains a similar amount of isolated/oligonuclear $\mathrm{Fe}(\mathrm{III})$ sites, but the fact that its $\mathrm{Fe}_{2} \mathrm{O}_{3}$ nanoparticle amount (Table 2 ) is higher than that of Fe(III)-USY-A (0.58 vs. $0.17 \mathrm{wt} \%$ ) causes its apparent activity value to be lower than that of $\mathrm{Fe}(\mathrm{III})$ USY-A (Fig. 9). An even worse case is $\mathrm{Fe}(\mathrm{III})-\mathrm{NaY}$. Fe(III)-NaY contains a quite high amount of isolated/oligonuclear Fe(III) sites, but its larger amount of $\mathrm{Fe}_{2} \mathrm{O}_{3}$ nanoparticles blocks many channels, leading to a much lower activity.

It is worth mentioning that the larger channel dimension can enhance the accessibility of iron sites sitting in zeolite channels, so FAU ([1 111$]$ ] $0.74 \times 0.74 \mathrm{~nm}$ ) appears to be a better host of active iron species than MFI ([ $\left.\begin{array}{lll}1 & 0 & 0\end{array}\right] 0.51 \times 0.55 \mathrm{~nm} \leftrightarrow\left[\begin{array}{lll}0 & 1 & 0\end{array}\right]$ $0.53 \times 0.56 \mathrm{~nm}$ ) and a better catalyst for $\mathrm{N}_{2} \mathrm{O}$ decomposition.

\subsection{Durability of Fe(III)-USY zeolite catalyst}

The high catalytic activity of $\mathrm{Fe}(\mathrm{III})$-USY for $\mathrm{N}_{2} \mathrm{O}$ decomposition motivates us to investigate the performance under simulated situations, such as with $\mathrm{O}_{2}(5 \%)$ and $\mathrm{NO}(150-200 \mathrm{ppm})$ in the exhaust stream, in order to clarify their effects on $\mathrm{N}_{2} \mathrm{O}$ decomposition. As seen in Fig. 10, the presence of $5 \% \mathrm{O}_{2}$ in the reaction system shows some negative effect on $\mathrm{N}_{2} \mathrm{O}$ decomposition. For example, $\mathrm{N}_{2} \mathrm{O}$ conversion was decreased by $5-10 \%$ at $650-725 \mathrm{~K}$. The inhibition effect of $\mathrm{O}_{2}$ on $\mathrm{N}_{2} \mathrm{O}$ decomposition is presumably related to the $\mathrm{N}_{2} \mathrm{O}$ decomposition mechanism. Since $\mathrm{O}_{2}$ can occupy the active sites to reduce $\mathrm{N}_{2} \mathrm{O}$ chemsorption and can inhibit the release of chemsorbed oxygen on the surface, the total conversion rate is thus partially prohibited.

In contrast, the existence of low concentration NO facilitates $\mathrm{N}_{2} \mathrm{O}$ decomposition. For example, the temperature at which

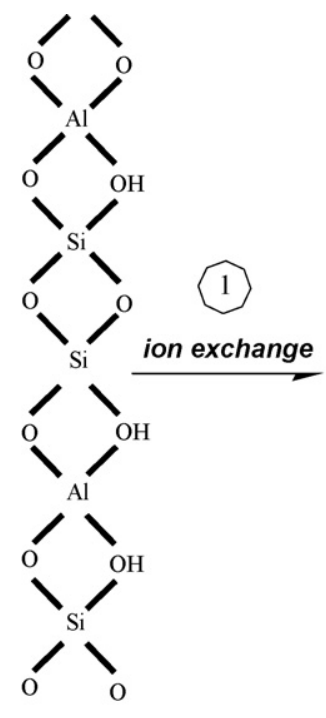

H-USY

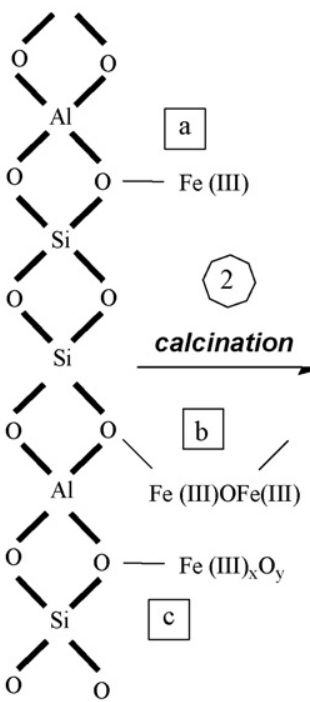

Fe(III)-USY

ion exchanged

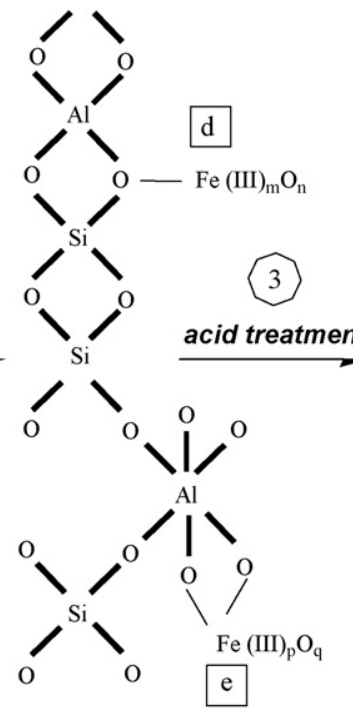

Fe(III)-USY

calcined
Fe(III)-USY
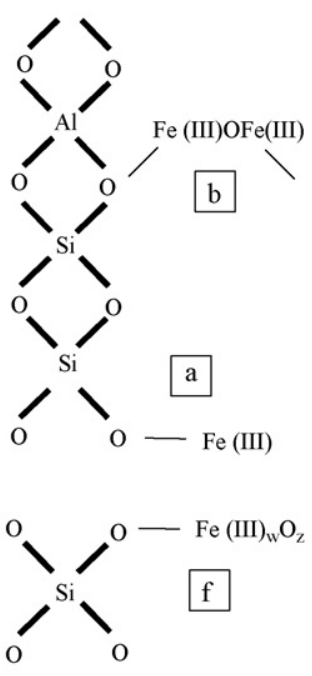

acid treated

Fig. 8. Schematic diagram for the formation of various iron species and the transformation of Al species in Fe(III)-USY. 

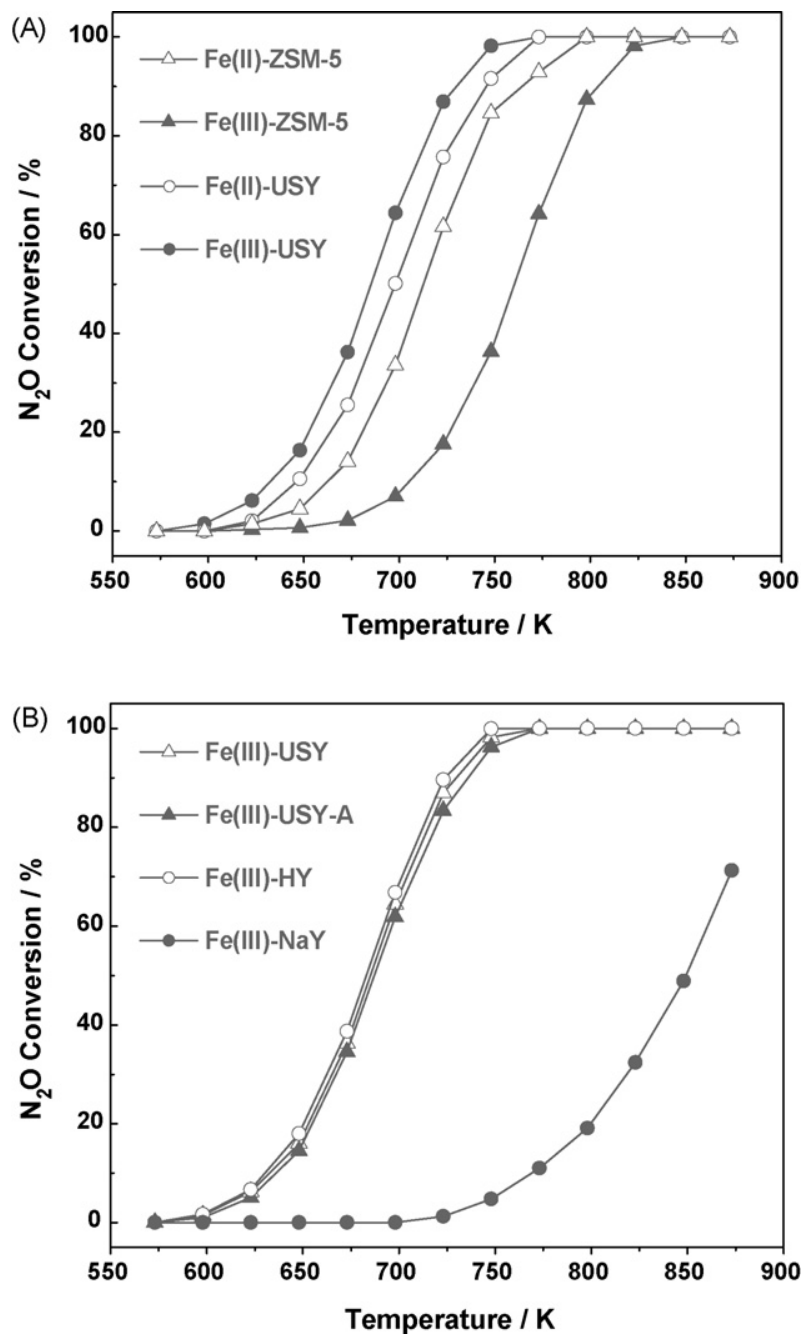

Fig. 9. Catalytic activities for $\mathrm{N}_{2} \mathrm{O}$ decomposition on $\mathrm{Fe}(\mathrm{II})-\mathrm{ZSM}-5$, Fe(III)-ZSM-5, $\mathrm{Fe}$ (II)-USY, $\mathrm{Fe}(\mathrm{III})$-USY (A); catalytic activities for $\mathrm{N}_{2} \mathrm{O}$ decomposition on $\mathrm{Fe}$ (III)-NaY, $\mathrm{Fe}(\mathrm{III})-\mathrm{HY}, \mathrm{Fe}(\mathrm{III})-\mathrm{USY}$ and Fe(III)-USY-t (B). Reaction conditions: $0.1 \mathrm{~g}$ catalyst, $1500 \mathrm{ppm} \mathrm{N}_{2} \mathrm{O}$ and the balance $\mathrm{He}, \mathrm{GHSV}=30,000 \mathrm{~h}^{-1}$.

$15-90 \% \mathrm{~N}_{2} \mathrm{O}$ conversion occurs is about $50 \mathrm{~K}$ lower after adding $200 \mathrm{ppm}$ NO (Fig. 10). The positive effect of $\mathrm{NO}$ on $\mathrm{N}_{2} \mathrm{O}$ decomposition over $\mathrm{Fe}(\mathrm{III})$-USY catalyst is consistent with the results reported for other iron-zeolites [49-51], and can basically be ascribed to promoting oxygen desorption from the active sites. When $\mathrm{O}_{2}(5 \%)$ and $\mathrm{NO}(200 \mathrm{ppm})$ coexist in the reaction system, a compositive function operates; as a result, a moderate positive effect is observed on $\mathrm{N}_{2} \mathrm{O}$ decomposition (Fig. 10).

We further tested the durability of $\mathrm{Fe}(\mathrm{III})$-USY catalyst under simulated conditions for a typical nitric acid plant, i.e. $1500 \mathrm{ppm}$ $\mathrm{N}_{2} \mathrm{O}, 200 \mathrm{ppm} \mathrm{NO}, 5 \% \mathrm{O}_{2}$ and $1 \% \mathrm{H}_{2} \mathrm{O}$ in He. Time-on-stream profiles in Fig. 11 show that the $\mathrm{N}_{2} \mathrm{O}$ conversion is $90-91 \%$ and $98-$ $99 \%$ at 723 and $748 \mathrm{~K}$, respectively, and remained almost unchanged for $100 \mathrm{~h}$, indicating that the catalyst is highly durable under these conditions. It is well known that Fe-ZSM-5 catalyst performs very well for $\mathrm{N}_{2} \mathrm{O}$ decomposition, but suffers from severe activity loss in the presence of water vapor. The deactivation of FeZSM-5 catalysts is due to the dealumination of zeolite framework and subsequent clustering of iron species [52]. As for Fe(III)-USY catalyst, the exchange of most protons in USY matrix with ferric ions reduces the proton-induced dealumination at higher temperatures. Moreover, formation of chemically bound $\mathrm{Al}-\mathrm{O}-\mathrm{Fe}$ species can protect $\mathrm{Fe}$ (III)-USY against dealumination, preserving a

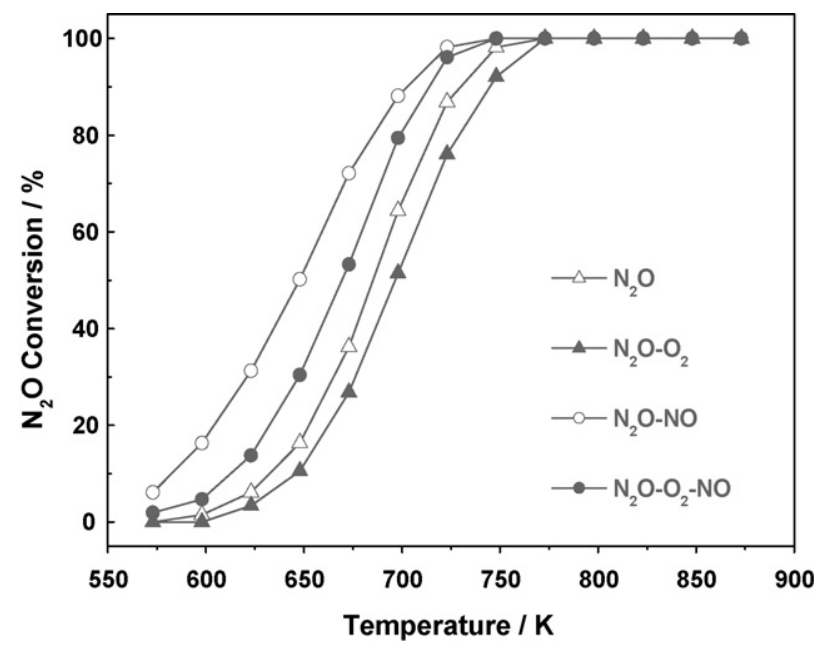

Fig. 10. Catalytic activities for $\mathrm{N}_{2} \mathrm{O}$ decomposition on $\mathrm{Fe}(\mathrm{III})$-USY under different conditions. Reaction conditions: 0.1 g catalyst, 1500 ppm $\mathrm{N}_{2} \mathrm{O}, 0$ or 200 ppm NO, 0 or $5 \% \mathrm{O}_{2}$ and the balance $\mathrm{He}, \mathrm{GHSV}=30,000 \mathrm{~h}^{-1}$.

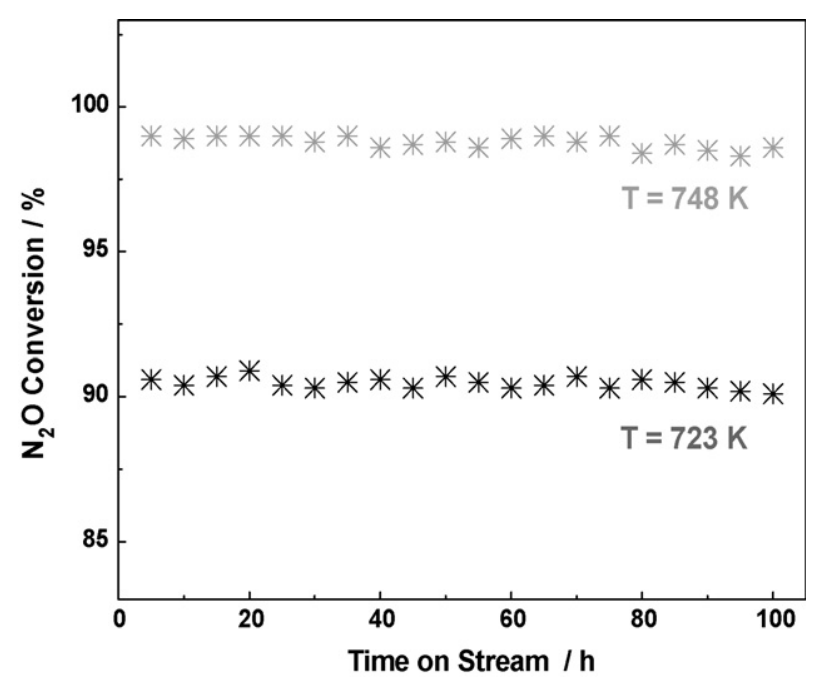

Fig. 11. Time-on-stream behavior of $\mathrm{Fe}(\mathrm{III})-\mathrm{USY}$ catalyst for $\mathrm{N}_{2} \mathrm{O}$ decomposition. Reaction conditions: $0.1 \mathrm{~g}$ catalyst, 1500 ppm $\mathrm{N}_{2} \mathrm{O}, 200 \mathrm{ppm} \mathrm{NO}, 5 \% \mathrm{O}_{2}, 1 \% \mathrm{H}_{2} \mathrm{O}$, balance $\mathrm{He}, \mathrm{GHSV}=30,000 \mathrm{~h}^{-1}$.

high durability of Fe(III)-USY catalyst. This durability has been also revealed by the ${ }^{27} \mathrm{Al} \mathrm{NMR}$ of calcined Fe(III)-USY catalyst (Fig. 7), which shows that there is no obvious change in intensity of peaks at 55 and $-5 \mathrm{ppm}$ before and after 100-h usage under the simulated conditions.

\section{Conclusions}

We prepared several Fe-zeolites with MFI and FAU structure via simple wet ion exchange, characterized their structural features and tested their catalytic performance for $\mathrm{N}_{2} \mathrm{O}$ decomposition. Thanks to the large channel dimension of FAU, $\mathrm{Fe}\left(\mathrm{H}_{2} \mathrm{O}\right)_{6}{ }^{2+}$ or $\mathrm{Fe}\left(\mathrm{H}_{2} \mathrm{O}\right)_{5}(\mathrm{OH})^{2+}$ directly diffuses into the channels and exchanges all protons, leading to a higher Fe loading. Multiple Fe(III) species, including isolated $\mathrm{Fe}(\mathrm{III})$ species (mononuclear or dinuclear oxygen bridged), oligonuclear $\mathrm{Fe}(\mathrm{III})_{x} \mathrm{O}_{y}$ clusters and $\mathrm{Fe}_{2} \mathrm{O}_{3}$ nanoparticles, were identified in all Fe-zeolites by means of UVvis, TEM, $\mathrm{H}_{2}$ TPR and FTIR of adsorbed NO. Formation of these various iron species was proposed on the basis of these 
observations and of ${ }^{27} \mathrm{Al} \mathrm{NMR} \mathrm{spectra} \mathrm{taken} \mathrm{for} \mathrm{each} \mathrm{step} \mathrm{of} \mathrm{the}$ preparation process. Fe-FAU catalysts exhibited a higher activity and a good durability for $\mathrm{N}_{2} \mathrm{O}$ decomposition under simulated conditions. Based on the structural characterization and catalytic performance, we propose that only the isolated/oligonuclear iron species with ready access to $\mathrm{N}_{2} \mathrm{O}$ molecules could have more contribution to $\mathrm{N}_{2} \mathrm{O}$ decomposition. $\mathrm{Fe}_{2} \mathrm{O}_{3}$ nanoparticles in catalysts played a negative role since they might block the channel of zeolites and reduce the accessibility of isolated/oligonuclear iron species in the channels.

\section{Acknowledgements}

This work was financially supported by the National Natural Science Foundation of China $(20725723,20703057)$ and National Basic Research Program of China (2004CB719500). The support from the ARC Centre for Functional Nanomaterials funded by the Australia Research Council under its Centre of Excellence Scheme is also appreciated.

\section{References}

[1] E.J.M. Hensen, Q. Zhu, R.A. van Santen, J. Catal. 220 (2003) 260.

[2] J. Jia, K.S. Pillai, W.M.H. Sachtler, J. Catal. 221 (2004) 119.

[3] H.Y. Chen, W.M.H. Sachtler, Catal. Today 42 (1998) 73.

[4] G. Delahay, D. Valade, A. Guzman-Vargas, B. Coq, Appl. Catal. B 55 (2005) 149.

[5] Q.S. Qi, R.T. Yang, Appl. Catal. B 60 (2005) 13.

[6] El-M. El-Malki, R.A. van Santen, W.M.H. Sachtler, J. Catal. 196 (2000) 212.

[7] J. Pérez-Ramírez, F. Kapteijin, G. Mul, X. Xu, J.A. Moulijn, Catal. Today 76 (2002) 55

[8] G.D. Pirngruber, M. Luechinger, P.K. Roy, A. Cecchetto, P. Smirniotis, J. Catal. 224 (2004) 429.

[9] J.A.Z. Pieterse, S. Booneveld, R.W. van den Brink, Appl. Catal. B 51 (2004) 215.

[10] E.V. Kondratenko, J. Pérez-Ramírez, J. Phys. Chem. B 110 (2006) 22586.

[11] A. Zecchina, M. Rivallan, G. Berlier, C. Lamberti, G. Ricchiardi, Phys. Chem. Chem. Phys. 9 (2007) 3483

[12] R.Q. Long, R.T. Yang, J. Am. Chem. Soc. 121 (1999) 5595

[13] A. Guzmán-Vargas, G. Delahay, B. Coq, Appl. Catal. B 42 (2003) 369.

[14] K. Sun, H. Xia, E. Hensen, R. van Santen, C. Li, J. Catal. 238 (2006) 186.

[15] G.D. Pirngruber, J. Catal. 219 (2003) 456.

[16] J. Pérez-Ramírez, J.C. Groen, A. Brückner, M.S. Kumar, U. Bentrup, M.N. Debbagh, L.A. Villaescusa, J. Catal. 232 (2005) 318.

[17] C.M. Fu, M. Deeba, W.K. Hall, Ind. Eng. Chem. Prod. Res. 19 (1980) 299.
[18] A.M. Zhang, C. Li, S.L. Bao, Q.H. Xu, Microporous Mesoporous Mater. 29 (1999) 383.

[19] J. Pérez-Ramírez, F. Kapteijin, G. Mul, J.A. Moulijn, J. Catal. 208 (2002) 211.

[20] L.D. Li, Q. Shen, J.J. Yu, Z.P. Hao, Z.P. Xu, G.Q. Max Lu, Environ. Sci. Technol. 41 (2007) 7901.

[21] J.A. Dean, Handbook of Chemistry, McGraw-Hill, New York, 1992.

[22] C.E. Housecroft, A.G. Sharpe, Inorganic Chemistry, Prentice Hall, Harlow, 2001.

[23] R.L. Martin, R.J. Hay, L.R. Pratt, J. Phys. Chem. A 102 (1999) 3565.

[24] G.J. Herdman, G.W. Neilson, J. Phys. Condens. Mater. 4 (1992) 649.

[25] P. Marturano, A. Kogelbauer, R. Prins, J. Catal. 190 (2000) 460.

[26] D.W. Breck, Zeolite Molecular Sieves, Wiley, New York, 1974.

[27] T. Remsungnen, B.M. Rode, J. Phys. Chem. A 107 (2003) 2324.

[28] I. Melián-Cabrera, C. Mentruit, J.A.Z. Pieterse, R.W. van den Brink, G. Mul, F. Kapteijn, J.A. Moulijn, Catal. Commun. 6 (2005) 301.

[29] Ch. Baerlocher, W.M. Meier, D.H. Olson, Atlas of Zeolitic Framework Types, Elsevier, 2001.

[30] K. Sato, Y. Nishimura, N. Matsubayashi, M. Imamura, H. Shimada, Microporous Mesoporous Mater. 59 (2003) 133.

[31] M.S. Kumar, M. Schwidder, W. Grünert, A. Brückner, J. Catal. 227 (2004) 384.

[32] L. Čapek, V. Kreibich, J. Dědeček, T. Grygar, B. Wichterlová, Z. Sobalíik, J.A. Martens, R. Brosius, V. Tokarová, Microporous Mesoporous Mater. 80 (2005) 279.

[33] G.D. Pirngruber, P.K. Roy, R. Prins, Phys. Chem. Chem. Phys. 8 (2006) 3939.

[34] P. Marturano, L. Drozdová, G.D. Pirngruber, A. Kogelbauer, R. Prins, R. Phys. Chem. Chem. Phys. 3 (2001) 5585.

[35] L.J. Lobree, I.-C. Wang, J.A. Reimer, A.T. Bell, J. Catal. 186 (1999) 242.

[36] El-M. El-Malki, R.A. van Santen, W.M.H. Sachtler, J. Phys. Chem. B 103 (1999) 4611.

[37] K.I. Hadjiivanov, Catal. Rev. Sci. Eng. 42 (2000) 71.

[38] M.A. Ulla, L.A. Aparicio, J.A. Dumesic, W.S. Millman, J. Catal. 117 (1989) 237.

[39] G. Mul, J. Pérez-Ramírez, F. Kapteijin, J.A. Moulijn, Catal. Lett. 80 (2002) 129.

[40] K. Segawa, Y. Chen, J.E. Kubsh, W.N. Delgass, J.A. Dumesic, W.K. Hall, J. Catal. 76 (1982) 112.

[41] E. Guglielminotti, J. Phys. Chem. 98 (1994) 9033.

[42] P.G. Harrison, E.W. Thornton, J. Chem. Soc. Faraday Trans. 74 (1978) 2703.

[43] W.J. Ji, Y. Chen, S.K. Shen, S.B. Li, H.L. Wang, Appl. Surf. Sci. 99 (1996) 151.

[44] Q. Zhu, B.L. Mojet, R.A.J. Jassen, E.J.M. Hensen, J. van Grondelle, P.C.M.M. Magusin, R.A. van Santen, Catal. Lett. 81 (2002) 205

[45] J.A. van Bokhoven, D.C. Koningsberger, P. Kunkeler, H. van Bekkum, A.P.M. Kentgens, J. Am. Chem. Soc. 122 (2000) 12842.

[46] J.H. Park, J.H. Choung, I.S. Nam, S.W. Ham, Appl. Catal. B 78 (2008) 342

[47] C. Pophal, T. Yogo, K. Yamada, K. Segawa, Appl. Catal. B 16 (1998) 177.

[48] J. Pérez-Ramírez, F. Kapteijn, A. Brückner, J. Catal. 218 (2003) 234.

[49] G. Mul, J. Pérez-Ramírez, F. Kapteijn, J.A. Moulijn, Catal. Lett. 77 (2001) 7.

[50] G.D. Pirngruber, J.A.Z. Pieterse, J. Catal. 237 (2006) 237.

[51] D. Kaucký, Z. Sobalík, M. Schwarze, A. Vondrová, B. Wichterlová, J. Catal. 238 (2006) 293.

[52] J.A.Z. Pieterse, G.D. Pirngruber, J.A. van Bokhoven, S. Booneveld, Appl. Catal. B 71 (2007) 16. 